of taxa in brown algae. In Irvine, D. E. G. \& Price, J. H. [Eds.] Modern Approaches to the Taxonomy of Red and Brown Algae. Systematic Assoc. Special Vol.10. Academic Press, London, pp. 339-69.

Schonbeck, M. \& Norton T. 1981. Growth forms of Fucus disticus in the San Juan Islands of Washington State. In Fogg, G. E. \& Jones, W. E. [Eds.] Proc. Int. Secweed Symp. 8:474-93.

Sideman, E. J. \& Mathieson, A. C. 1983a. Ecological and genecological distinctions of a high intertidal, dwarf form of Fucus distichus (L.) Powell. J. Exp. Mar. Biol. Ecol. 72:171-88. - 1983b. The growth, reproductive phenology and longevity of non-tide pool Fucus distichus (L.) Powell in New England. J. Exp. Mar. Biol. Ecol. 68:111-27.
Sokal, R. T. \& Rohlf, J. F. 1969. Biometry. W. H. Freeman and Co., San Francisco, 776 pp.

- 1981. Biometry. 2nd ed. W. H. Freeman and Co., San Francisco, 856 pp.

South, G. R. 1976. A check-list of marine algae of eastern Canada-first revision. J. Mar. Biol. Ass. U.K. 56:817-43.

South, G. R. \& Hooper, R. 1981. A catalogue and atlas of the benthic marine algae of the island of Newfoundland. Memorial University of Newfoundland Occasional Papers in Biology, No. 3, 136 pp.

Taylor, W. R. 1962. Marine Algae of the Northeastern Coast of North America, 2nd revised ed. Univ. of Michigan Press, Ann Arbor, 509 pp.

\title{
AN ASSESSMENT OF ECOLOGICAL CHANGES DURING THE RECENT HISTORY OF LAKE ONTARIO BASED ON SILICEOUS ALGAL MICROFOSSILS PRESERVED IN THE SEDIMENTS ${ }^{1,2}$
}

\author{
E. F. Stoermer, ${ }^{3}$ J. A. Wolin, C. L. Schelske, and D. J. Conley \\ Great Lakes Research Division, The University of Michigan, Ann Arbor, Michigan 48109
}

\begin{abstract}
Quantitative analysis of siliceous algal microfossils (diatoms and chrysophytes) in a radiometrically dated core of Lake Ontario sediments shows striking modifications of the flora produced and preserved, apparently as a result of anthropogenic modification of nutrient loadings to the lake. Qualitatively similar microfossil assemblages were deposited during the period ca. 1700-1815. A single major event is recorded in assemblages deposited ca. 1769. Between this event horizon and ca. 1815 there was an apparent increase in algal production, but minimal change in species composition. A major disturbance occurred at the level of the Ambrosia horizon, ca. 1831-1847. Assemblages deposited between ca. 1855 and 1900 indicate increasing eutrophication. We infer that silica limitation became important by about 1860 and that the system reached its greatest effective production ca. 1900. Major modification of the flora occurred in the period ca. 19001945, with most local extinctions of major indigenous populations occurring ca. 1920-1945. Assemblages deposited in the period ca. 1945-1975 are composed of some stenothermal populations also present in pre-disturbance assemblages, a large component of benthic and nearshore planktonic species, and a number of apparently planktonic populations rarely recorded from large temperate lakes, particularly species of the genus Nitzschia. Our results indicate that the major factor driving species succession in Lake Ontario was phosphorus enrichment and conse-
\end{abstract}

\footnotetext{
${ }^{1}$ Accepted: 14 January 1985.

${ }^{2}$ Contribution No. 407 of the Great Lakes Research Division, University of Michigan.

${ }^{3}$ Address for reprint requests.
}

quent depletion of available silica supplies. Our results also show the importance of a species' physical niche in determining its survival under these conditions.

Key index words: diatoms; paleolimnology; eutrophication; Laurentian Great Lakes; biogenic silica

Lake Ontario is the terminal member of the Great Lakes system and because of its position, receives the influence of material loadings into the upper lakes. Also because of its geographic position, it was the first of the Great Lakes to be influenced by the activities of European settlers in North America. These influences have been prolonged and intense. The effects of early settlement activities on the invertebrate fauna (Warwick 1980) and algal flora (Stoermer et al., unpublished data) are detectable in sediments of the Bay of Quinte, a large bay of the lake, prior to 1700 . During the modern era undesirable ecological changes in Lake Ontario have become a matter of widespread concern and this has generated extensive attempts at remedial action.

Some of the problems of practical concern in Lake Ontario are directly related to modification of the algal flora. Overgrowth of Cladophora glomerata (L.) Kütz. causes severe nuisances in many areas of the lake and has been extensively investigated (Wolfe and Sweeney 1982). The modern phytoplankton flora has an unusual species composition and is characterized by large and apparently unstable seasonal and annual shifts in composition and abundance (Nalewajko 1967, Ogawa 1969, Munawar and Nauwerck 1971, Stoermer et al. 1974). For example, intense spring blooms of species such as Stephano- 
discus binderanus (Lorifice and Munawar 1974, Stoermer et al. 1974) sometimes cause odor and filtration problems at municipal water treatment facilities (Schenk and Thompson 1965), and surface scums and reduction in water clarity associated with high phytoplankton abundance adversely affect recreational uses of the lake.

At a more fundamental level, it has gradually become appreciated that the Lake Ontario ecosystem has become seriously dysfunctional, apparently as a result of human modification. Elevated levels of primary production (Vollenweider et al. 1974) are not reflected by enhanced fisheries production. There have been extensive invasions or introductions of exotic populations, at all trophic levels, including many species with primarily marine distribution. A conspicuous example is the red alga Bangia atropurpurea (Roth) Ag. which has become established in Lake Ontario and other localities in the Great Lakes system (Lin and Blum 1977).

The cause and mechanisms involved in apparent compositional and functional changes have become the topic of considerable interest and debate. This has been fueled by practical considerations involving water quality, but there is a growing awareness that human modification of the Great Lakes system presents interested investigators with an experiment which, although unplanned and uncontrolled, could provide valuable clues about the structure and function of large aquatic systems, if it could be deciphered. This is an exciting possibility. The scale and interactions involved would be difficult to simulate in the laboratory or in the field. Trends in population succession which usually operate on geological time scales have been compressed into a few decades. Thus systems such as Lake Ontario offer the possibility of investigating questions of both practical and theoretical interest on dimensions of time and geographical scale which are rarely available.

As these possibilities begin to be explored, it has become evident that the Great Lakes provide a fertile ground for testing various theories about the control of ecosystem structure and function. For those interested in the effects of conservative ion concentration on organism distribution, there have been substantial changes in major ion concentrations in Lake Ontario (Beeton 1965) which are timecorrelated with changes in the biota. For those interested in biological control of ecosytem function there have been major changes in fish and invertebrate communities (Beeton 1969, Smith 1972) which are also time-correlated with other changes in the system. The effects of persistent toxic chemicals in the environment could also be addressed in the Lake Ontario case, since the Niagara region was one of the sites of early development of the North American chemical industry and this lake has been subjected to particularly large and diverse toxic chemical loadings. Perhaps the predominant theory of cause for changes in Lake Ontario algal communities is eutrophication. It is generally agreed that increased loading of nutrients, particularly phosphorus, is a primary cause of increased production and the most probable cause of species succession. On the basis of these considerations, management practices have been instituted to limit phosphorus loadings to the Great Lakes system in general and to Lake Ontario in particular. Evidence has been presented (e.g. Dobson 1981) that these efforts have been successful and that the levels of available phosphorus in the lake are decreasing. If this is indeed the case, it may be that the "Lake Ontario experiment" is entering a new phase. The reaction of a system which has faced ca. 200 years of increasing nutrient loads to a reversal in this trend will be interesting to observe. At the present time there is a lively debate about what this reaction will be and the importance of other modifying factors.

We have been particularly interested in the effects of nutrient loading on the abundance and species composition of the algal flora. On the basis of nutrient addition experiments, we (Schelske and Stoermer 1971, 1972) projected that increased phosphorus loadings to Lake Michigan would result in depletion of silica and a shift in dominance from diatoms to members of other physiological groups, such as green and blue-green algae which do not require silicon for growth. A critical assumption in this hypothesis is that excess silica flux generated by eutrophication is permanently stored in the sediments and that annual flux to the sediments equals, or exceeds, annual inputs from the watershed. According to this hypothesis, silica flux to the sediments should be relatively low and stable prior to eutrophication because diatom growth is limited by phosphorus availability, rises to a peak as phosphorus loadings increase and available silica supplies in the water column are depleted, then declines to lower levels governed by silica inputs and recycling. A corollary to this argument is that diatom populations adapted to growth at high temperatures in the summer epilimnion would be affected first by silica limitation, followed by species adapted to growth in the metalimnetic chlorophyll maximum (Moll and Stoermer 1982) and eventually by populations which have their growth optimum during winter circulation.

Parker and Edgington (1976) concluded that storage of biogenic silica in the form of diatom frustules was not demonstrable in Lake Michigan sediments. In the core they examined, they found a logarithmic decrease in abundance of diatom frustules down core. They concluded that Lake Michigan sediments are not an important sink for biogenic silica and that reduced silica concentrations in the surface waters result from increased diatom standing crop.

Frederick (1981) found maximum diatom abundance at depth in a core from Lake Erie and a declining trend in abundance toward the surface. Al- 
though Frederick expressed puzzlement over the apparent trend toward lower diatom production in light of the known history of eutrophication in Lake Erie, Schelske et al. (1983) used Frederick's results as evidence supporting the silica depletion hypothesis. Schelske et al. (1983) also presented data on biogenic silica concentration in cores from Lake Michigan and Lake Ontario in support of their conclusion that maximum biogenic silica storage in Great Lakes sediments occurs early in the eutrophication sequence.

Theriot and Stoermer (1984) examined morphological trends in Stephanodiscus niagarae populations in the Lake Erie core which Frederick (1981) studied. They found morphological changes in this species consistent with those found in populations growing under varying $\mathrm{P} / \mathrm{Si}$ ratios in several North American lakes (Theriot 1983) and concluded this was evidence for historic silica depletion in Lake Erie.

Thus, there is evidence for major changes in the algal flora of the Great Lakes. A dominant mechanism has been postulated, but there is less than general agreement on its importance. Lake Ontario seems an appropriate locality to further study this problem. It has the longest history of human influence on the Great Lakes and modern silica concentrations in the water column are the lowest of any lake in the system (Dobson et al. 1974, Weiler 1981). Previous studies (Duthie and Sreenivasa 1971) have shown abundant diatoms preserved in its sediments and qualitative evidence of eutrophication from changes in species composition.

We undertook the study described below with two objectives in mind: (1) To resolve, in greater detail, the history of modifications of the Lake Ontario algal flora based on algal remains preserved in its sediments. (2) To attempt to interpret this history in terms of the most likely mechanisms. The approach adopted was quantitative analysis of algal remains preserved in a dated core.

\section{MATERIALS AND METHODS}

The core used in this study was taken by Dr. R. A. Bourbonniere (Canada Centre for Inland Waters, Burlington) as part of the Great Lakes HISED project. The core was obtained from an offshore depositional basin $\left(43^{\circ} 30.2^{\prime} \mathrm{N} ; 76^{\circ} 54.1^{\prime} \mathrm{W}\right)$ on 8 May 1981. The sampling site is nominally the same investigated by Duthie and Sreenivasa (1971).

The core was sectioned at $1 \mathrm{~cm}$ intervals to a depth of $20 \mathrm{~cm}$ and at $2 \mathrm{~cm}$ intervals thereafter. The sectioned material was homogenized and subsamples were withdrawn for the various specific analyses performed. The material was then freeze-dried to permit dry weight measurements without problems of compaction and microfossil breakage introduced by air drying.

Dates reported here were developed by Dr. J. A. Robbins (NOAA-GLERL, Ann Arbor) using ${ }^{210} \mathrm{~Pb}$ methods described by Robbins and Edgington (1975) and Robbins (1978).

Biogenic silica analyses used the methods developed by DeMaster (1979, 1981). Subsamples of 20-30 mg of dry sediment were digested in $50 \mathrm{~mL}$ of a $1 \% \mathrm{Na}_{2} \mathrm{CO}_{3}$ solution at $85^{\circ} \mathrm{C}$ in polypropylene centrifuge tubes. One $\mathrm{mL}$ aliquots were removed after $2,3.5$, and $5 \mathrm{~h}$ and analyzed for dissolved silica by the heteropoly blue method (Davis and Simmons 1979). The biogenic silica concentration was determined by fitting a line by least squares regression to extracted silica vs. time and the extrapolated intercept, at time zero, taken as the biogenic silica concentration of the sample. This technique relies on the difference between rapid dissolution of biogenic silica and the slower dissolution of silica from other minerals in the samples (DeMaster 1979).

We restricted our microscopic investigation to siliceous microfossils. Carbonaceous algal remains are abundant in the surficial sediments of Lake Ontario, but virtually absent from samples more than $5 \mathrm{~cm}$ below the sediment surface. It is our conclusion that they are not adequately preserved, at least at the site sampled, to permit meaningful analysis.

For siliceous microfossil analysis, weighed subsamples of the raw sediment were cleaned by the $\mathrm{H}_{2} \mathrm{O}_{2}$ method (Battarbee 1979). After washing by decanting distilled water rinses to remove oxidation byproducts, measured subsamples of the cleaned material were transferred to Battarbee chambers (Battarbee 1979) and the material was allowed to dry onto cover glasses under controlled conditions. The material was then permanently mounted in Hyrax (Patrick and Reimer 1966).

Replicate slides were prepared from each sample and replicate transects were enumerated on each slide. Enumeration followed the procedure developed by Glover (1982). All recognizable algal remains, including both whole diatom valves and chrysophyte cysts and scales and fragments of these structures, were counted and the proportion of the whole morphological unit constituted by a given fragment recorded. In further analysis, the various fragment categories were mathematically "reconstituted" and reported in terms of the base morphological unit. Since we were dealing with a fairly restricted flora, most fragments could be assigned to a species, but some small fragments could only be determined by the generic level or noted as a fragment of a diatom valve or chrysophyte cyst. All enumeration was done with a Leitz Ortholux microscope equipped with fluorite oil immersion objectives and an optical system providing ca. 1200 magnifications and numerical aperture of $1.30^{+}$

Raw count data were encoded and further processed with a locally developed data base management system (FIDO). Further plotting and statistical analyses were performed using the University of Michigan Computer Center's operating system (MTS) and statistical package (MIDAS). Several types of multivariate analyses were performed. Results obtained were essentially similar. We will illustrate and discuss cluster analyses based on the Euclidean distance measure and average distance clustering method (Carney 1982).

\section{RESULTS}

A total of 187 morphological entities were recorded during the study. Of this total, 158 are diatoms, 27 are chrysophyte cysts, 1 is a chrysophyte scale, and 1 is a cyst of uncertain affinity. Many of the species and cyst types occurred in very low abundance or only in a few samples and will not be discussed further. Complete data listings can be obtained from the senior author. The original samples and voucher specimens of taxa discussed are available in the diatom collection, Great Lakes Research Division, University of Michigan.

Sample numbers, the depths represented by each sample, and the median date for each sample interval are given in Table 1. The dates presented are based entirely on ${ }^{210} \mathrm{~Pb}$-derived estimates; however, Robbins et al. (1978) have shown good correspondence between ${ }^{210} \mathrm{~Pb}$ dates and dates derived from the Ambrosia horizon in Lake Ontario. 
TABLE 1. Sample numbers, corresponding sample intervals, and date of intervals for Core LO 81-E 30. Sample intervals are given in depth (cm) from the sediment surface at time of sampling (1981). Dates are estimates for the midpoint of each interval based on ${ }^{210} \mathrm{~Pb}$. The calculated mass sedimentation rate is $0.0391 \mathrm{~g} / \mathrm{cm}^{2} / \mathrm{yr}$.

\begin{tabular}{ccc}
\hline \hline Sample no. & Sample interval & Estimated date \\
\hline 1 & $0.0-1.0$ & $1979 \pm 2$ \\
2 & $1.0-2.0$ & $1976 \pm 4$ \\
3 & $2.0-3.0$ & $1972 \pm 4$ \\
4 & $3.0-4.0$ & $1967 \pm 4$ \\
5 & $4.0-5.0$ & $1962 \pm 4$ \\
6 & $5.0-6.0$ & $1957 \pm 5$ \\
7 & $6.0-7.0$ & $1952 \pm 6$ \\
8 & $7.0-8.0$ & $1945 \pm 7$ \\
9 & $8.0-9.0$ & $1938 \pm 6$ \\
10 & $9.0-10.0$ & $1932 \pm 7$ \\
11 & $10.0-11.0$ & $1924 \pm 7$ \\
12 & $11.0-12.0$ & $1917 \pm 7$ \\
13 & $12.0-13.0$ & $1910 \pm 8$ \\
14 & $13.0-14.0$ & $1903 \pm 8$ \\
15 & $14.0-15.0$ & $1896 \pm 7$ \\
16 & $15.0-16.0$ & $1889 \pm 8$ \\
17 & $16.0-17.0$ & $1881 \pm 8$ \\
18 & $17.0-18.0$ & $1874 \pm 9$ \\
19 & $18.0-19.0$ & $1867 \pm 8$ \\
20 & $19.0-20.0$ & $1859 \pm 10$ \\
21 & $20.0-22.0$ & $1847 \pm 17$ \\
22 & $22.0-24.0$ & $1831 \pm 18$ \\
23 & $24.0-26.0$ & $1815 \pm 16$ \\
24 & $26.0-28.0$ & $1800 \pm 17$ \\
25 & $28.0-30.0$ & $1785 \pm 18$ \\
26 & $30.0-32.0$ & $1769 \pm 20$ \\
27 & $32.0-34.0$ & $1752 \pm 19$ \\
28 & $34.0-36.0$ & $1736 \pm 21$ \\
29 & $36.0-38.0$ & $1719 \pm 20$ \\
30 & $38.0-40.0$ & $1704 \pm 20$ \\
\hline
\end{tabular}

The trends in total siliceous microfossil abundance and chemically determined biogenic silica are shown in Figure 1. The trends present are qualitatively similar, but there are some important differences. Total microfossil abundance is similar in the lowermost four samples, then declines to a minimum at sample 26 (1769). Following this, numbers increase progressively until sample 22 and then decline in samples 21 and $20(1847-1859)$. Abundance then immediately rises to the highest levels observed in sample 19 (1867). Following this, microfossil numbers generally decline, except for increases in samples 6-8 (1945-1957) and in the surficial sediments. Biogenic silica values show more uniform values in the lower section of the core and peak in samples 20 and 21 , which were where lower numbers of siliceous microfossils occurred.

Trends in major microfossil types are shown in Figure 2. Diatoms dominate the assemblage in all samples. As would be expected, planktonic species are the most important component, although benthic species are quite abundant in some samples. Chrysophyte remains are a minor fraction of microfossils found in all samples. The preservation of small diatom fragments is highest in the lower section of

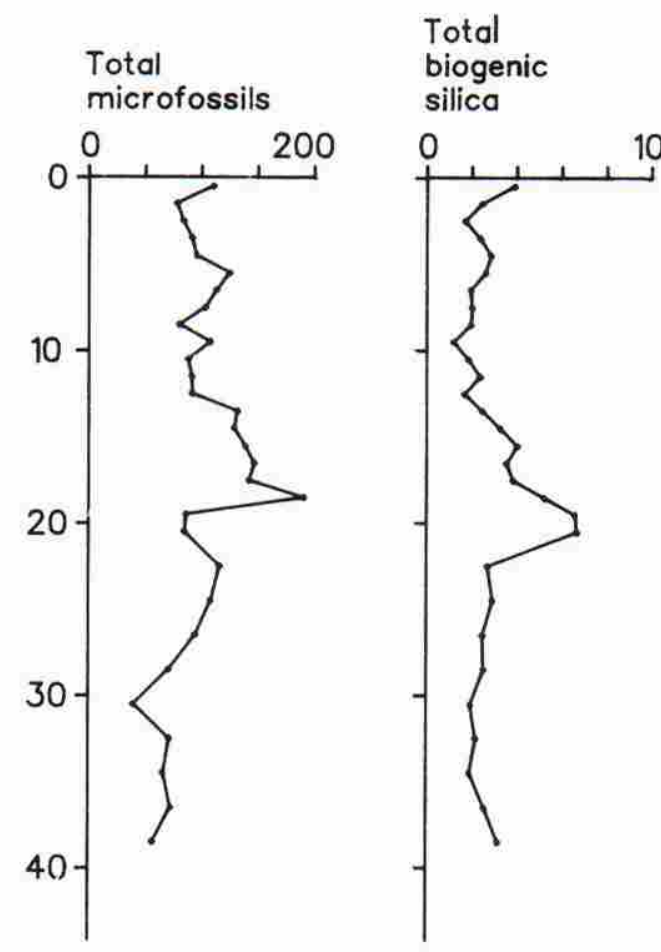

FIG. 1. Total abundance of siliceous microfossils (diatom valves and chrysophyte cysts) and corresponding amount of biogenic silica in samples. Vertical scale is depth $(\mathrm{cm})$ in core from sediment surface (1981). Horizontal scale units are no. $\times 10^{6} / \mathrm{g}$ dry wt sediment for microfossils and $\mathrm{mg} \mathrm{BSiO}_{2} / \mathrm{g}$ dry wt sediment for biogenic silica.

the core, then declines to low, and nearly constant values as in sample 22 (1831) and thereafter.

The genus Cyclotella (Fig. 3) is a fairly minor component of assemblages in the lower section of the core, rises to peak abundance in samples deposited between ca. 1850 and 1900 , then declines to virtual local extinction after ca. 1950. Several different local trends are found in the major species.

Cyclotella comensis has a unique bimodal distribution, with maximum absolute and relative abundance in samples 22 (1831) and 14 (1903). Even more unusual, this species goes from less than detectable numbers to maximum abundance between two sample intervals. The distribution and ecology of this species are poorly known. It is reported to occur in abundance in alpine lakes in Europe (Huber-Pestalozzi 1942), but is rarely reported in North America. It is present in the modern flora of the upper Great Lakes (Stoermer 1978) and recently has become much more abundant in Lakes Michigan (Stoermer 1984a) and Huron (Stoermer and Kreis 1980). In Lake Huron, population maxima are associated with high nitrate levels and low levels of available silica, apparently because $C$. comensis is able to utilize silica in low concentrations during summer blooms (Stoermer and Kreis 1980). It reaches maximum abundance during the summer in the upper 

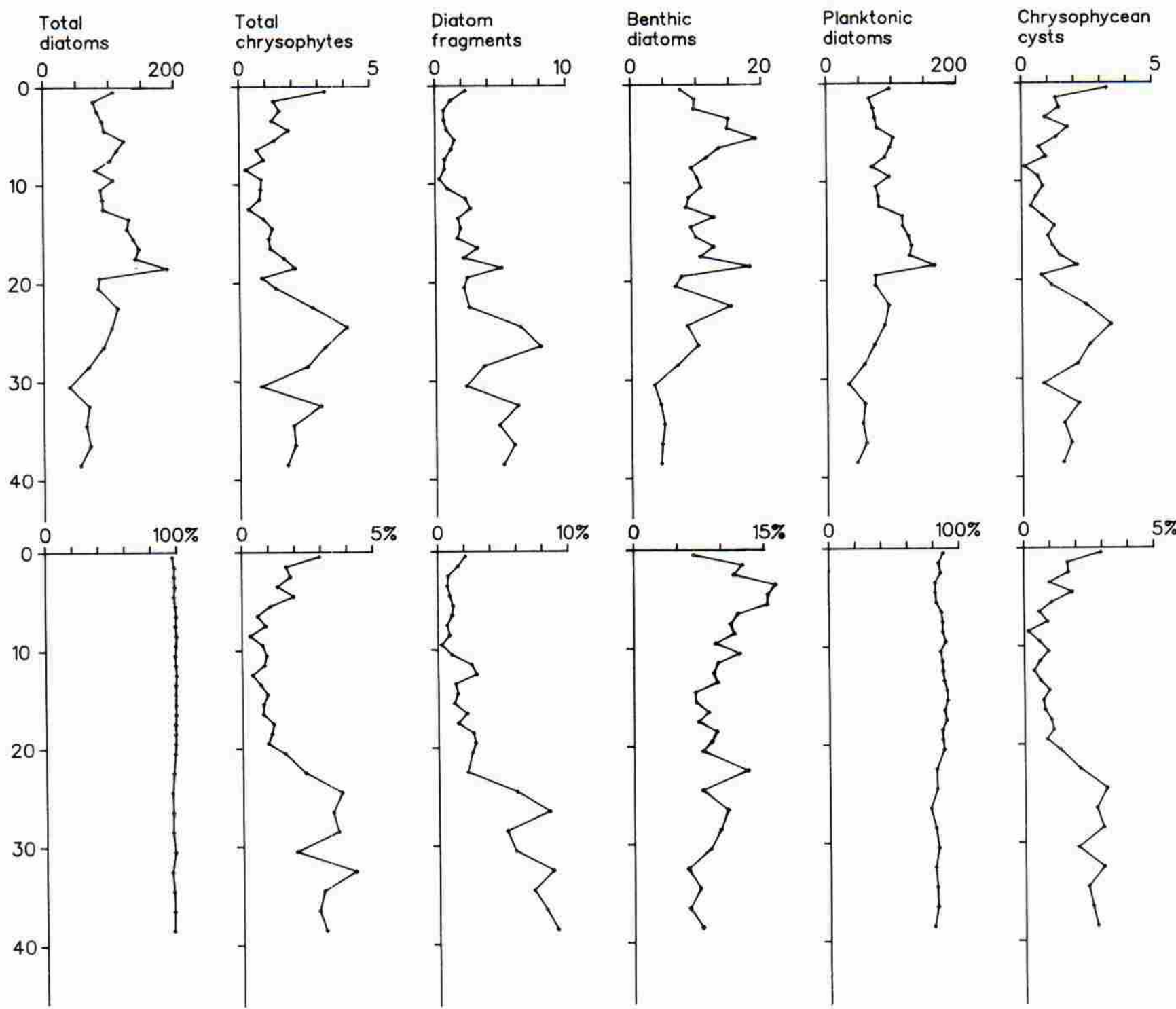

F1G. 2. Absolute (no. $\times 10^{6} / \mathrm{g}$ dry wt sediment) and relative (\%) abundance of major microfossil types in core. Vertical scale units are centimeters from sediment surface (1981).

lakes and, unlike most diatoms, forms auxospores during summer blooms. Keilty (unpublished data) has found $C$. comensis in recent surficial sediments of Lake Erie but hypothesizes that these populations are derived from Lake Huron.

Cyclotella comta is widely distributed in oligotrophic and mesotrophic lakes throughout the north temperate region (Huber-Pestalozzi 1942). It is common in summer phytoplankton assemblages from the least modified parts of the upper Great Lakes. Maximum abundance of this species is found at temperatures of ca. $19^{\circ} \mathrm{C}$ (Stoermer and Ladewski 1976 , Stoermer 1978). In our samples, it is a minor component of assemblages in the deep sediments but shows a generally increasing trend in absolute abundance above $30 \mathrm{~cm}$.

Cyclotella michiganiana is similar to C. comta in its regional and seasonal distribution in the upper Great Lakes, but is rarely reported from outside the Great Lakes region. It was originally described from Lake Michigan (Skvortzow 1937). In Lake Michigan, maximum abundance occurs at temperatures near $20^{\circ} \mathrm{C}$ (Stoermer and Ladewski 1976). In Lake Ontario sediments, only occasional occurrences were noted below sample 22 (1831) when the species became fairly abundant and remained so until sample 16 (1889). Only a few occurrences were noted above this, the last in sample 8 (1945).

Cyclotella ocellata is widely reported from a variety of lake types. In the Great Lakes it appears to be particularly associated with least disturbed regions (Stoermer 1978). It does not show a clear pattern of maximum abundance at a particular temperature range in Lake Michigan (Stoermer and Ladewski 


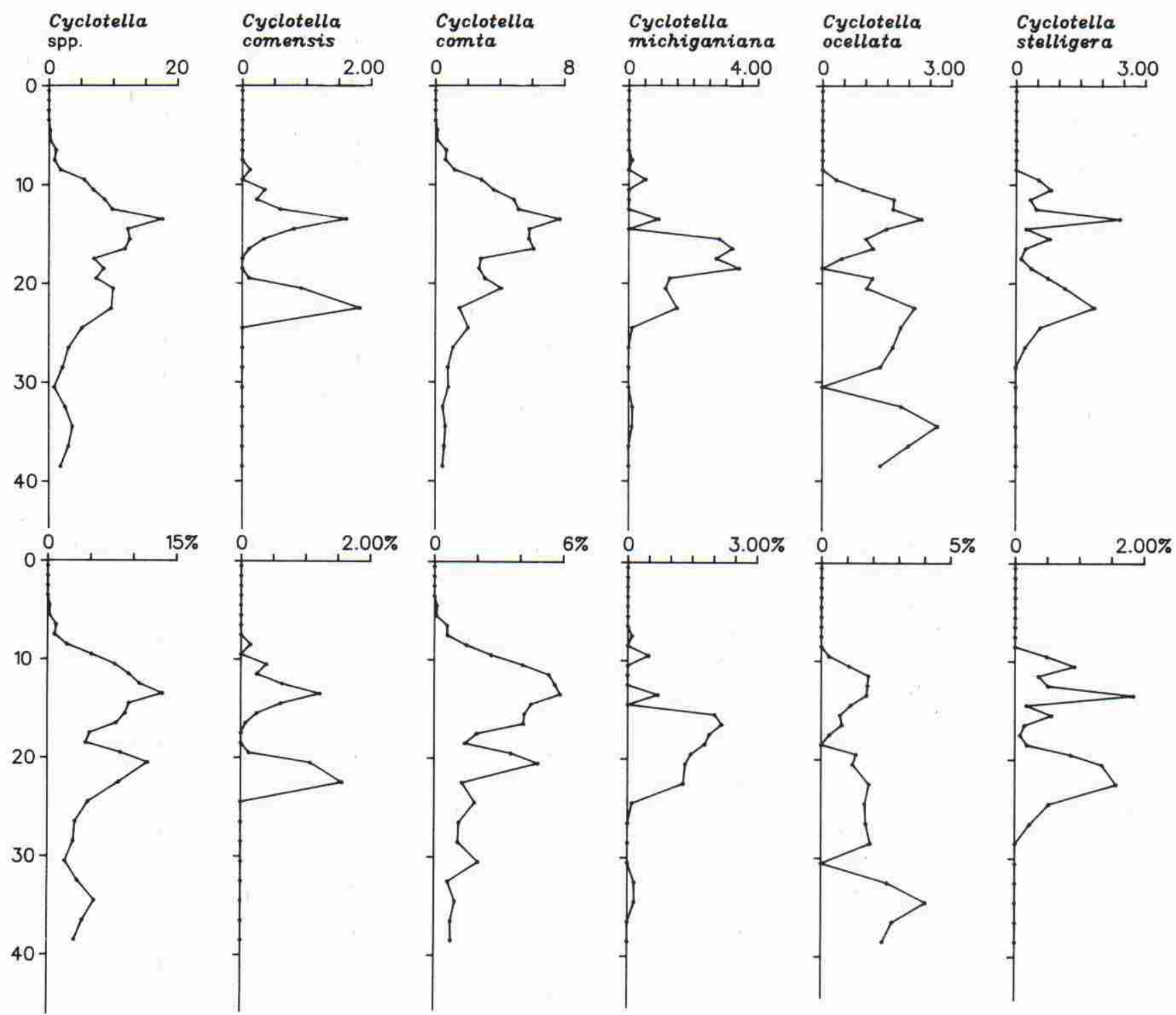

FIG. 3. Absolute (upper panel) and relative (lower panel) abundance of Cyclotella and some of its major species in core. Units are as in Figure 2.

1976). This appears to be related to the fact that it is most abundant in the metalimnetic chlorophyll maximum (Moll and Stoermer 1982) and summer occurrences in the surface waters are associated with summer upwelling events (Stoermer and Kreis 1980). This species has a peculiar cyclic pattern of occurrence in Lake Ontario sediments, unlike any of the other major populations noted in our study. Absolute abundance maxima occur in samples 28 (1736), 22 (1831), and 14 (1903). Absolute abundance minima occur in samples 26 (1769), 19 (1867), and 9 (1938). It does not recover from the last decline and no occurrences were noted in samples 9 and above. Relative abundance is greater in samples below 30 $\mathrm{cm}$ depth and relative abundance is more uniform than absolute abundance in samples between 20-30 $\mathrm{cm}$ depth in the core.
Cyclotella stelligera has a bimodel pattern of abundance, somewhat similar to that of $C$. comensis. Maximum abundance occurs in samples 14 and 22 and there is a pronounced minimum at sample 18 , as in C. comensis. Cyclotella comensis, however, has both its first and last occurrences somewhat lower in the section than does $C$. stelligera. Cyclotella stelligera is widely distributed in the upper Great Lakes (Stoermer 1978), but appears to be more tolerant of eutrophication than other Cyclotella sp. discussed above. Populations in Lake Michigan (Schelske and Stoermer 1972) and Lake Superior (Schelske et al. 1972) show rapid growth response to experimental phosphorus additions. Maximum abundance in Lake Michigan occurs at temperatures near $20^{\circ} \mathrm{C}$ (Stoermer and Ladewski 1976).

Members of the genus Fragilaria (Fig. 4) did not 

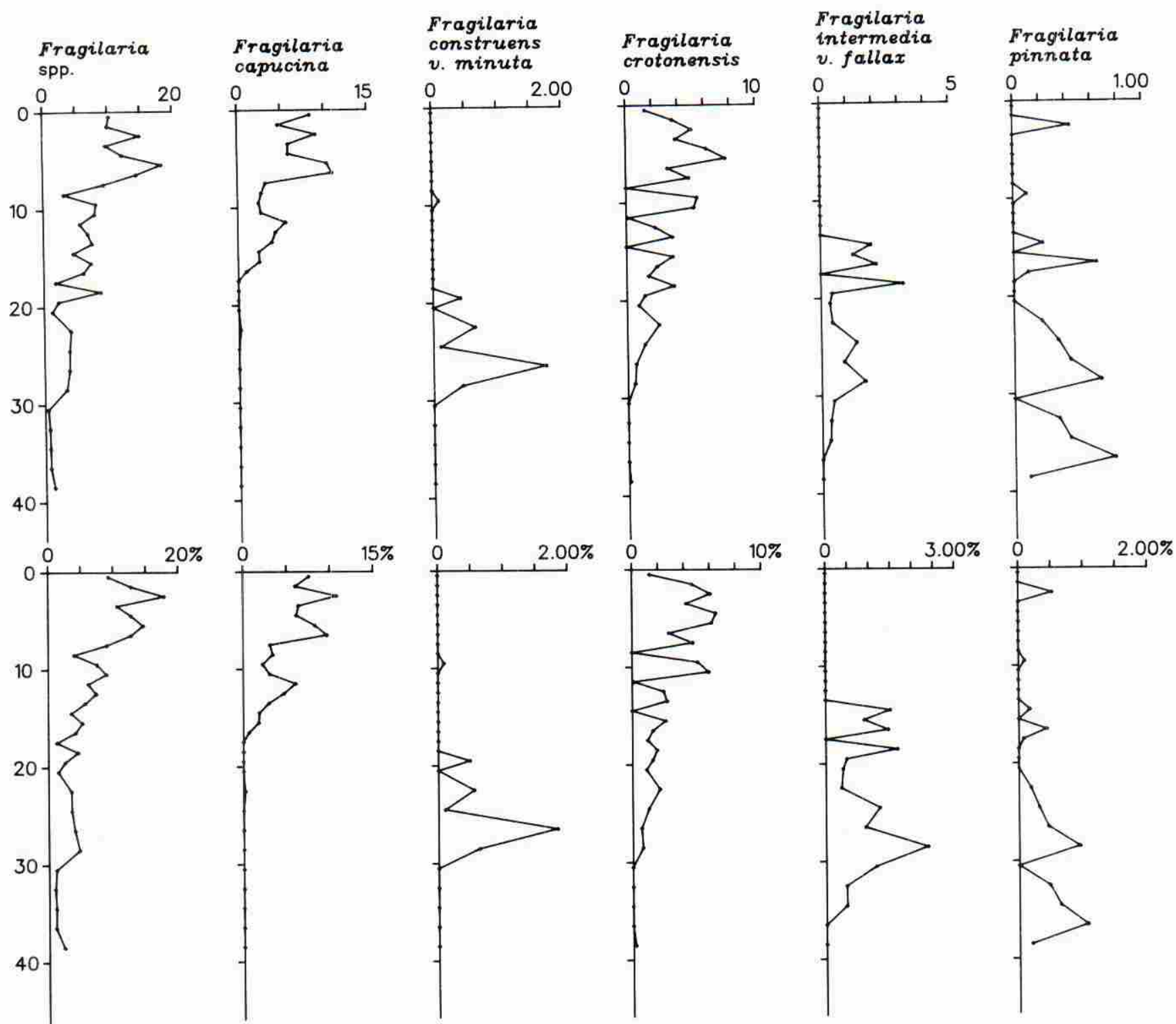

FIG. 4. Absolute (upper panel) and relative (lower panel) abundance of Fragilaria and some of its major species in core. Units are as in Figure 2.

exhibit a consistent pattern of abundance. The abundance of Fragilaria species is low in samples below $30 \mathrm{~cm}$, somewhat higher in samples between 20 and $30 \mathrm{~cm}$, then undergoes a generally increasing trend to the surficial sediments. Individual species, however, show quite different responses.

Fragilaria capucina is usually associated with eutrophied conditions in the Great Lakes. It is most abundant in shallow bays and marginal lakes which receive heavy nutrient loads (Stoermer 1978), and is one of the species which underwent a marked increase in abundance in Lake Erie between 1935 and 1965 (Hohn 1969). It is usually not abundant in offshore waters, possibly because of its relatively heavy silicification (Sicko-Goad et al. 1977), but occasional populations have been noted in the offshore waters of Lake Ontario, particularly in the spring and fall (Stoermer et al. 1974). Its greatest abundance is found at temperatures near $9^{\circ} \mathrm{C}$ (Stoermer and Ladewski 1978). An isolated occurrence of $F$. capucina was noted in sample 22 (1831), but it did not become abundant and continuously present until sample 17 (1881).

Fragilaria construens var. minuta is a minor element of phytoplankton assemblages in the upper Great Lakes. It rarely occurs in significant abundance and little is known about its distribution and ecology, although most records come from least modified parts of the system. It first occurs in sample 25 (1785), reaches maximum abundance in sample 24 (1800), then declines to undetectable levels after sample 20 (1859), except for a single occurrence in sample 10 (1932).

Fragilaria crotonensis is an apparently very tolerant 
"weed" species which occurs under a variety of conditions in the Great Lakes and most other large, temperate lakes. It is one of few species which shows a positive response to nitrate addition under experimental conditions (Stoermer et al. 1978), and one of the few diatoms to reach maximum abundance at temperatures $>10^{\circ} \mathrm{C}$ in Lake Ontario (Stoermer and Ladewski 1978). It first occurs in sample 25 (1785), and gradually increases in abundance to sample 16 (1889). The general trend of increase continues after this, but there are wide fluctuations in abundance. Maximum absolute abundance occurs in sample 6 (1957) and abundance decreases toward the top of the section.

Fragilaria intermedia var. fallax is a common element of offshore phytoplankton assemblages in the upper Great Lakes (Stoermer 1978) but is rarely recorded from other habitats. On the basis of distribution, it appears limited to oligotrophic conditions. According to Stoermer and Yang (1970), it is an indigenous member of the Lake Michigan flora and modern occurrences are restricted to offshore waters, particularly in the northern part of the lake. It is most abundant in Lake Michigan at temperatures near $4^{\circ} \mathrm{C}$ (Stoermer and Ladewski 1976). In our core, it first occurs in sample 28 (1736) and is present, except for sample 18 (1874), up to sample 15 (1896). No occurrences are noted above this level.

Fragilaria pinnata is a primarily benthic species which is commonly entrained into plankton communities in the upper Great Lakes (Stoermer and Yang 1970, Stoermer and Kreis 1980). It is very rare in modern plankton collections from Lake Ontario (Stoermer et al. 1974). It undergoes an unusual cycle of abundance in the core samples. It reaches an early peak in abundance in sample 29 (1719), then progressively decreases to very low abundance in sample 26 (1769). It then rises to another abundance peak in sample 25 (1785), and again progressively declines to near zero abundance in sample 21 (1847). It is not consistently present in samples above this, but isolated occurrences were noted in sample 17 (1881) and 3 (1972).

The genus Melosira (Fig. 5) contains two species dominant in sediment assemblages from Lake Ontario, and two others which show interesting trends.

Melosira distans is a minor floral component, with a single significant peak in abundance centered around sample 21 (1847). It is of interest because it is the only member of the genus which appears to be restricted to oligotrophic habitats in the modern Great Lakes (Stoermer 1978).

Melosira granulata occupies the opposite end of the trophic spectrum in the modern Great Lakes. It is found in abundance only in the most eutrophic areas and is often a summer dominant in such regions (Stoermer et al. 1981). It is not particularly abundant in the modern offshore phytoplankton flora of Lake Ontario (Stoermer et al. 1974), and maximum abundance tends to occur at lower temperatures (Stoermer and Ladewski 1978) than it does in other regions of the Great Lakes. It is consistently present in the lower section of the core and undergoes a cycle of decline and resurgence before reaching a singular peak in abundance in sample 19 (1867). All of the specimens observed in samples up to and including sample 19 are of the narrow, finely-structured form (M. granulata var. angustissima $\gamma$ status). The species does not occur again until sample 15 (1896) and this, and all subsequent occurrences, are of the coarsely-structured form ( $\alpha$ status). The species is somewhat less abundant and more erratic in occurrence after this transition. Andresen (1976) noted a similar transition in morphology in his study of postsettlement diatom succession in Douglas Lake, Michigan and attributed it to material loading effects probably resulting from a major fire in the lake's drainage basin.

Melosira islandica is a common winter and early spring dominant throughout the Great Lakes system. Its maximum abundance occurs at temperatures of $7-8^{\circ} \mathrm{C}$ in Lake Michigan (Stoermer and Ladewski 1976), and Lake Ontario (Stoermer and Ladewski 1978). During summer stratification, significant populations are found only in the metalimnion and below except during upwellings. Since this is the most abundant member of the genus in our samples, its trend in absolute abundance is nearly the same as that described for the genus as a whole. Both absolute and relative abundance, however, decline after sample 20 (1859), rather than forming a plateau of near constant abundance for the interval between samples 20 and 15 .

The reason for this is a peak in $M$. italica subsp. subarctica centered around sample 16 (1889). This species is an important component of assemblages in the lower section of the core, declines to a minimum at sample 20 (1859), then, after reaching peak abundance, declines very rapidly to local extinction. The last specimens observed were found in sample 10 (1932). The ecology of this species in the Great Lakes is not very well known since it appears to be a strictly winter and sub-thermocline dominant. It commonly co-occurs with $M$. islandica, but its maximum abundance is at temperatures of ca. $5^{\circ} \mathrm{C}$ in Lake Michigan (Stoermer and Ladewski 1976) and it appears less tolerant of nutrient stress.

One of the striking features of modern phytoplankton assemblages in Lake Ontario is the unusual abundance of members of the genus Nitzschia in plankton assemblages (Stoermer et al. 1974). Members of the genus are present in all levels of the core (Fig. 6), but the abundance patterns of the major species differ considerably.

Nitzschia confinis first occurs in samples 22 and 21 (1831-1847) but its major peak in abundance centers around sample 6 (1957). Most reports of this species come from large tropical lakes (Hustedt 


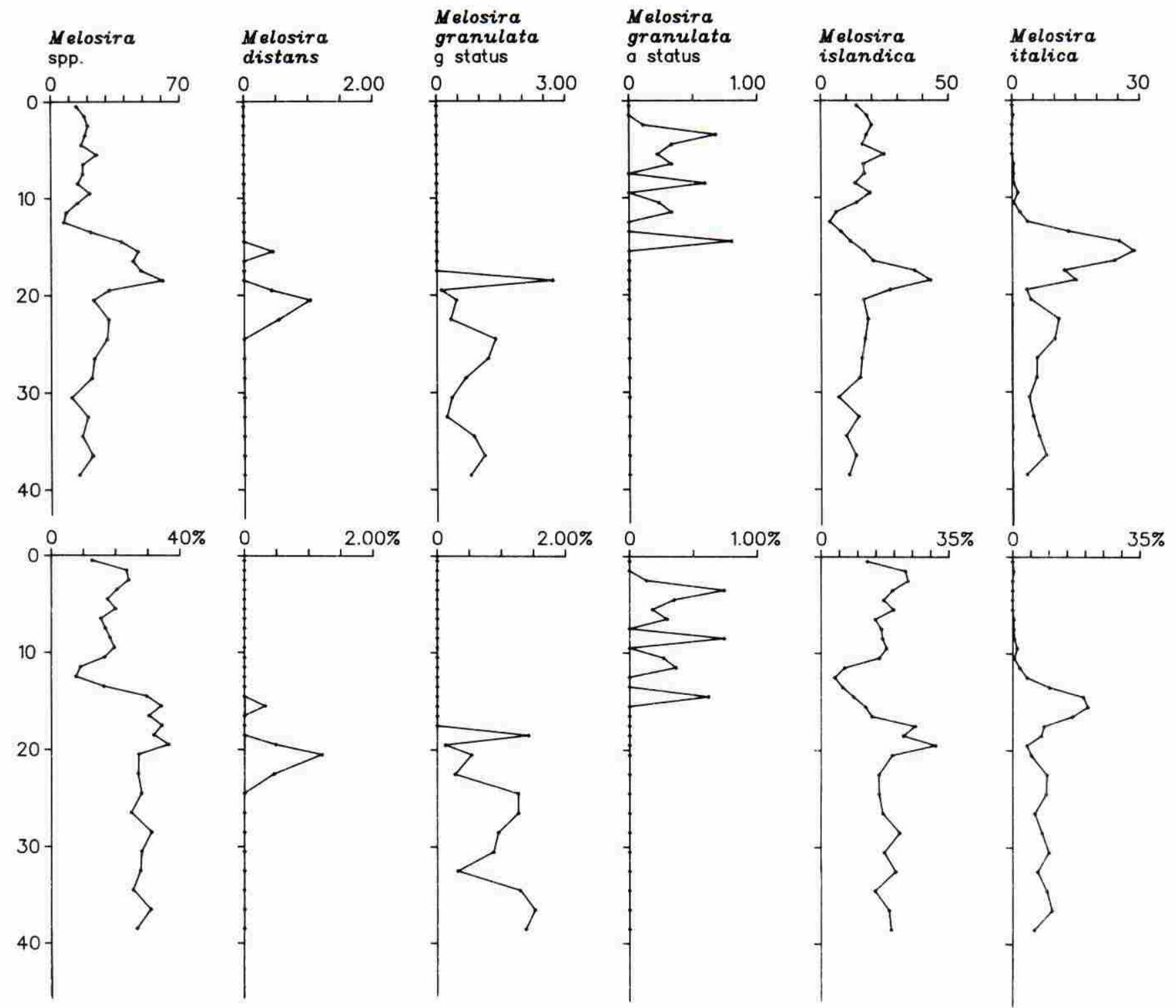

Fig. 5. Absolute (upper panel) and relative (lower panel) abundance of Melosira and some of its major species and growth forms in core. Units are as in Figure 2.

1949), but it was common in Lake Michigan in the early 1970 s with maximum abundance in early summer at temperatures near $15^{\circ} \mathrm{C}$ (Stoermer and Ladewski 1976). According to Stoermer and Yang (1969), this species did not occur in Lake Michigan prior to ca. 1937.

Nitzschia dissipata was common in Lake Ontario in samples investigated by Stoermer et al. (1974) and apparently has been present in the lake throughout the period represented by our core. Main abundance maxima are around samples 6 and 5 (19571962) and sample 17 (1881). It is not commonly reported from plankton collections (e.g. Huber-Pestalozzi 1942), but has been noted in Lake Michigan (Stoermer and Yang 1970), Lake Erie (Hohn 1969), and Lake Huron (Stoermer and Kreis 1980), so it is apparently widely distributed in the Great Lakes system. Maximum abundance occurs at temperatures near $3^{\circ} \mathrm{C}$ in Lake Ontario (Stoermer and Ladewski 1978).

Nitzschia sp. \#1 is a small species of uncertain affinities which has been noted in modern plankton collections from Lake Michigan. In our samples it has a single peak in abundance centered around sample 6 (1957).

Nitzschia sp. \#2 is a large member of the genus, similar to and perhaps identical to $N$. lauenburgiana Hust. It is a common element of early spring plankton communities in Lake Michigan (Stoermer and Yang 1970), Lake Huron (Stoermer and Kreis 1980), as well as Lake Ontario (Stoermer et al. 1974). In Lake Ontario it is most abundant at temperatures 

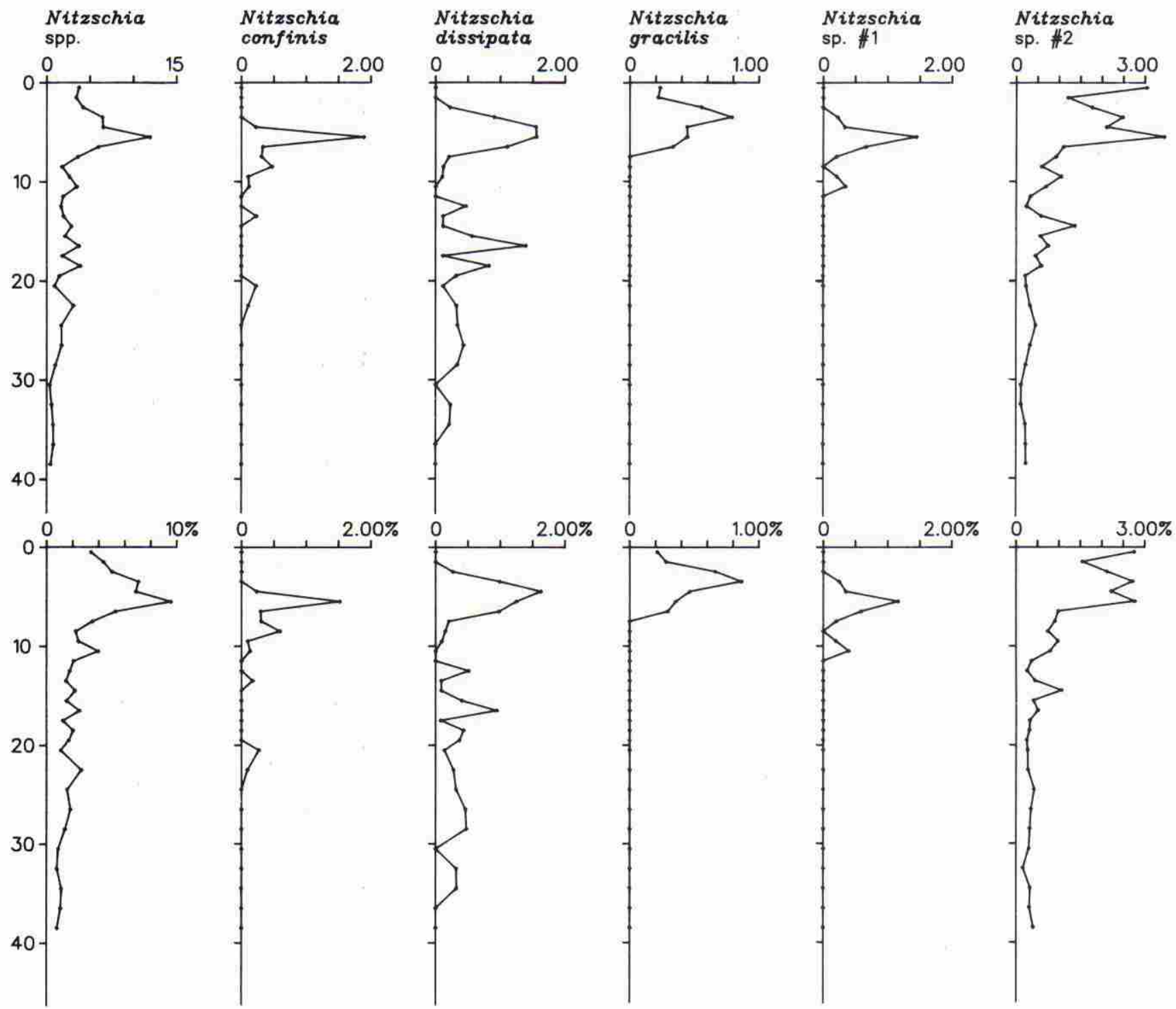

Fig. 6. Absolute (upper panel) and relative (lower panel) abundance of Nitzschia and some of its major species in core. Units are as in Figure 2.

around $4^{\circ} \mathrm{C}$ (Stoermer and Ladewski 1978). This species is present in all samples from the core. It has a minor peak in abundance around sample 15 (1896), but is most abundant in sample 6 (1957), and thereafter.

Members of the genus Stephanodiscus (Fig. 7) are an important part of diatom assemblages in all levels of the core sampled. Numbers of Stephanodiscus show a generally increasing trend between 40 and $20 \mathrm{~cm}$ in the core, with minor inflections at sample 26 (1769) and 20 (1859). Absolute abundance of the genus sharply increases at sample 19 (1867) and remains high until sample 6 (1957). After this, absolute abundance declines before returning to higher levels in the surficial sediments.

Stephanodiscus alpinus is an important component of assemblages throughout the core. Absolute abun- dance increases slightly between 40 and $20 \mathrm{~cm}$, then increases more rapidly and erratically from 20 to 10 $\mathrm{cm}$. Maximum absolute abundance occurs in sample 8 (1945), then decreases before rising again in samples deposited after sample 3 (1972). The trend in relative abundance is smoother, with an accelerating rising trend above $20 \mathrm{~cm}$. Maximum relative abundance is also found in sample 8 (1945), then declines before returning to near maximal levels in the top two samples. The distribution and ecological affinities of this species are difficult to determine because it is apparently often reported as $S$. astraea (Ehrenb.) Grun, S. astraea var. minutula Grun. and perhaps other illegitimate epithets (Håkansson and Locker 1981). The species apparently has highly variable morphology (Håkansson and Stoermer 1984), especially in the Great Lakes (Theriot and Stoermer 

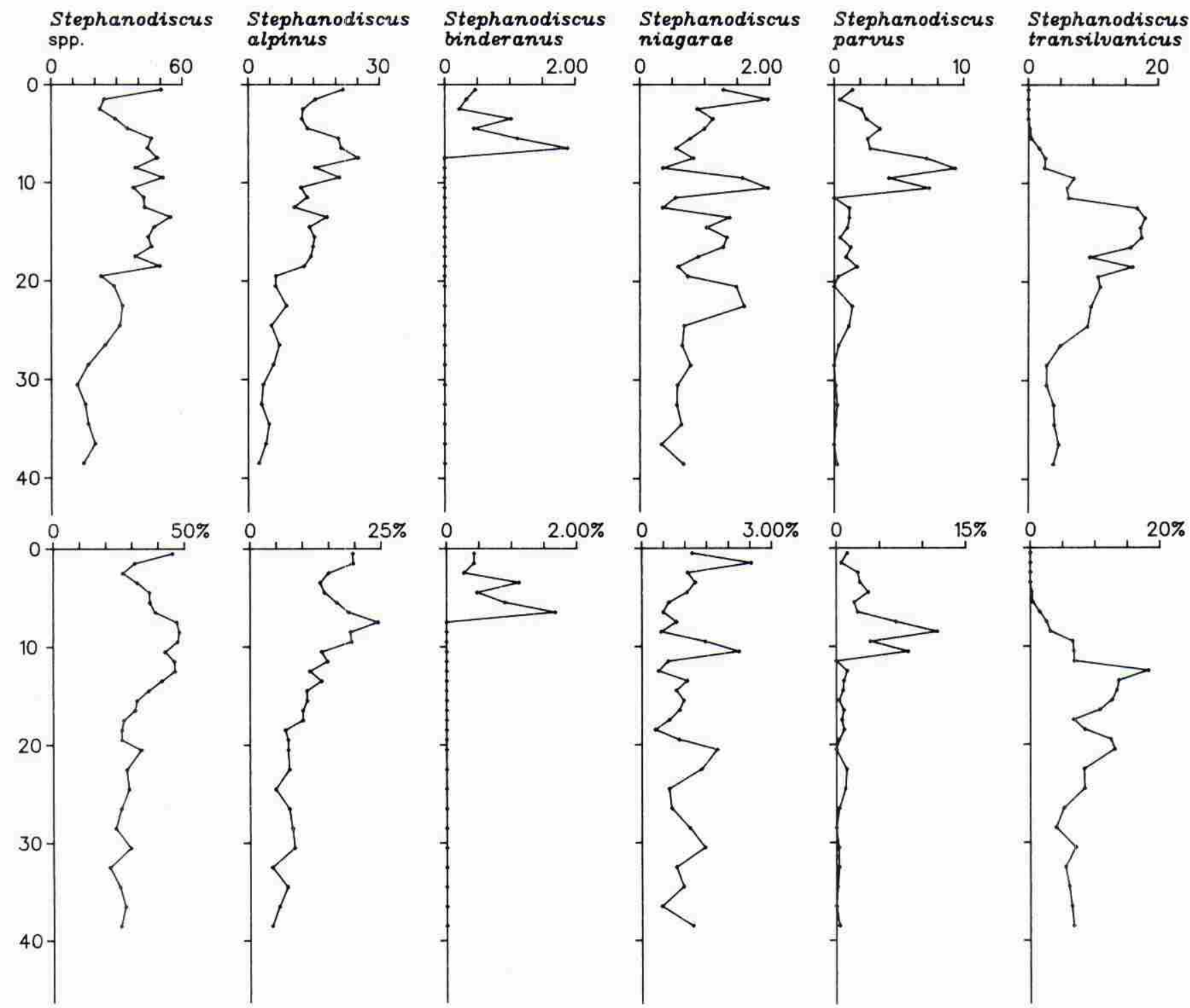

Fig. 7. Absolute (upper panel) and relative (lower panel) abundance of Stephanodiscus and some of its major species in core. Units are as in Figure 2.

1982). In our material, S. alpinus appears to undergo a consistent change in morphology similar to that described by Theriot and Stoermer (1984) in S. niagarae, but we have not verified this quantitatively. It is widely distributed throughout the Great Lakes system and appears to be tolerant of widely different nutrient loading conditions, but sensitive to temperature. Estimated temperature of maximum abundance is ca. $1.5^{\circ} \mathrm{C}$ for Lake Michigan populations (Stoermer and Ladewski 1976), and $0^{\circ} \mathrm{C}$ for Lake Ontario populations (Stoermer and Ladewski 1978). The species is thus apparently restricted primarily to winter or sub-thermocline growth.

The occurrence of $S$. binderanus in the core is much more restricted. Maximum abundance is found in its first occurrence in sample 7 (1952) and it declines in abundance thereafter. This species was first reported from the Great Lakes region by Brunel (1956) who noted that blooms of $S$. binderanus caused problems at the Montreal municipal filtration plant in November 1955. Similar occurrences in the Chicago region of Lake Michigan were reported by Vaughn (1961). Hustedt (1930) reported that this species is found in highly eutrophic and slightly saline waters in Europe. In the Great Lakes, S. binderanus is particularly associated with the excursion of the spring thermal bar (Stoermer 1968, Lorifice and Munawar 1974) and maximum abundance occurs at temperatures of $8-9^{\circ} \mathrm{C}$ (Stoermer and Ladewski 1976, 1978). In the upper lakes, occurrences are restricted to nearshore waters, but in Lake Ontario significant populations are found in all regions of the lake (Stoermer et al. 1974).

Stephanodiscus niagarae occurs in lakes of a wide 
variety of trophic states (Theriot 1983). It was originally described from Niagara Falls (Ehrenberg 1846), and has been a minor component of the Lake Ontario flora for the entire time period covered by our core. In the modern Great Lakes, S. niagarae is most abundant in the most eutrophic parts of the system, although small populations can be found in nearly any region. Maximum abundance usually occurs in early spring, ca. $4^{\circ} \mathrm{C}$ in Lake Ontario (Stoermer and Ladewski 1978), which is consistent with its pattern of occurrence in other lakes (Theriot 1983). Populations in this core appear to undergo the same change in morphology discussed by Theriot and Stoermer (1984), although we have not formally verified this.

The entity which we report here as $S$. parous has evidently been reported under a number of different names in the literature (Stoermer and Håkansson 1984). As a result, it is difficult to sort out its range of occurrence but it appears to be one of the most common small members of the genus in highly eutrophic bodies of water. Like other species which occupy such habitats (Stoermer et al. 1979, Håkansson and Stoermer 1984), it is highly polymorphic. Only small populations are found in the lower and mid-portions of the core, but it reaches a peak in abundance in samples 11-8 (1924-1945), and then progressively declines to low abundance in the surficial sediments.

There is also a certain amount of taxonomic confusion regarding the species we report here as $S$. transilvanicus. Populations with the general morphology of this species are much more common in Plio-Pleistocene deposits than in modern lakes, and the species which occurs in the Great Lakes may be more closely related to $S$. subtransilvanicus, as described by Gasse (1980), than to $S$. transilvanicus proper. Whatever its correct name, the population we treat here is widely distributed in the modern upper Great Lakes system. It is most abundant in oligotrophic, offshore waters during the winter and early spring. Maximum abundance occurs at temperatures near $6^{\circ} \mathrm{C}$ in Lake Michigan (Stoermer and Ladewski 1976). It is apparently absent from the modern flora of Lake Ontario (Stoermer et al. 1974) but is a dominart part of sediment assemblages below ca. $10 \mathrm{~cm}$.

Abundance trends in a number of other diatom species of potential interpretative interest are shown in Figure 8.

Actinocyclus normanii fo. subsalsa is considered one of the most pollution tolerant species in the modern Great Lakes system (Stoermer 1978). It is most common in shallow, eutrophic areas such as western Lake Erie (Hohn 1969), Green Bay of Lake Michigan (Stoermer and Yang 1969), and Saginaw Bay of Lake Huron (Stoermer and Theriot 1983). It is uncommon in recent (1972) samples from the offshore waters of Lake Ontario (Stoermer et al. 1974), and is one of the few diatoms with maximum abundance at temperatures near $20^{\circ} \mathrm{C}$. It is interesting to note that the 1972 collections coincide with its maximum abundance in the core at sample 3 (1972). First occurrence of this species was noted in sample 8 (1938).

Asterionella formosa is a very widely distributed species which is apparently tolerant of a wide range of conditions. It was first noted in sample 16 (1889), and is most abundant between sample 11 (1924), and sample 6 (1957).

Diatoma tenue var. elongatum is another species abundant in eutrophic regions of the Great Lakes (Stoermer 1978). It first occurs in sample 16 (1889) and begins to increase in abundance at sample 8 (1945). Peak abundance is reached in sample 4 (1967) and it declines slightly after this.

Surirella angusta normally occurs in benthic habitats and Stoermer et al. (1974) commented on its unusual abundance in the winter flora of Lake Ontario. Its maximum abundance is at temperatures between 3 and $4^{\circ} \mathrm{C}$ (Stoermer and Ladewski 1976).

Populations reported as Synedra ulna may include more than one variety of this taxon since end shape, which is critical in varietal determination (Patrick and Reimer 1966), may not be seen in broken specimens. The majority of specimens belong to $S$. ulna var. chaseana Thomas, which is an offshore dominant in the upper Great Lakes, although assemblages in the upper part of the core may include $S$. ulna var. ulna, which is primarily benthic, and $S$. ulna var. danica (Kütz.) V.H., a planktonic variety more tolerant of eutrophic conditions.

In the Great Lakes, the genus Tabellaria contains a number of morphotypes which cannot be adequately separated in fossil material. The dominant population is probably $T$. flocculosa sensu Knudson (1953). Tabellaria spp. are moderately abundant in all samples from the core, with notable peaks in abundance in samples 19 and 18 (1867-1874), 7 (1952), and in the surficial sediments. Relative abundance remains high after sample 7 . A notable low occurs in sample 26 (1769). Tabellaria is common in modern spring and fall samples from Lake Ontario (Stoermer et al. 1974) and it is most abundant at temperatures near $7^{\circ} \mathrm{C}$ (Stoermer and Ladewski 1978).

Chrysophycean cysts (Fig. 9) are a minor component of sediment assemblages (Fig. 2), but several morphotypes have interesting patterns of distribution (Fig. 9). Unfortunately, most cannot be identified with living species so they were given arbitrary designations.

The form designated chrysophycean cyst $\# 3$ is abundant in the lower samples in the core, then declines to low relative abundance after sample 25 (1785). Significant peaks occur up core in samples 19 and 18 (1867-1874), and 15 (1896). This entity was last noted in sample 7 (1952).

The form designated as chrysophycean cyst \#19 was first noted in sample 28 (1736), and is consistently present in samples above number 21 (1847). 

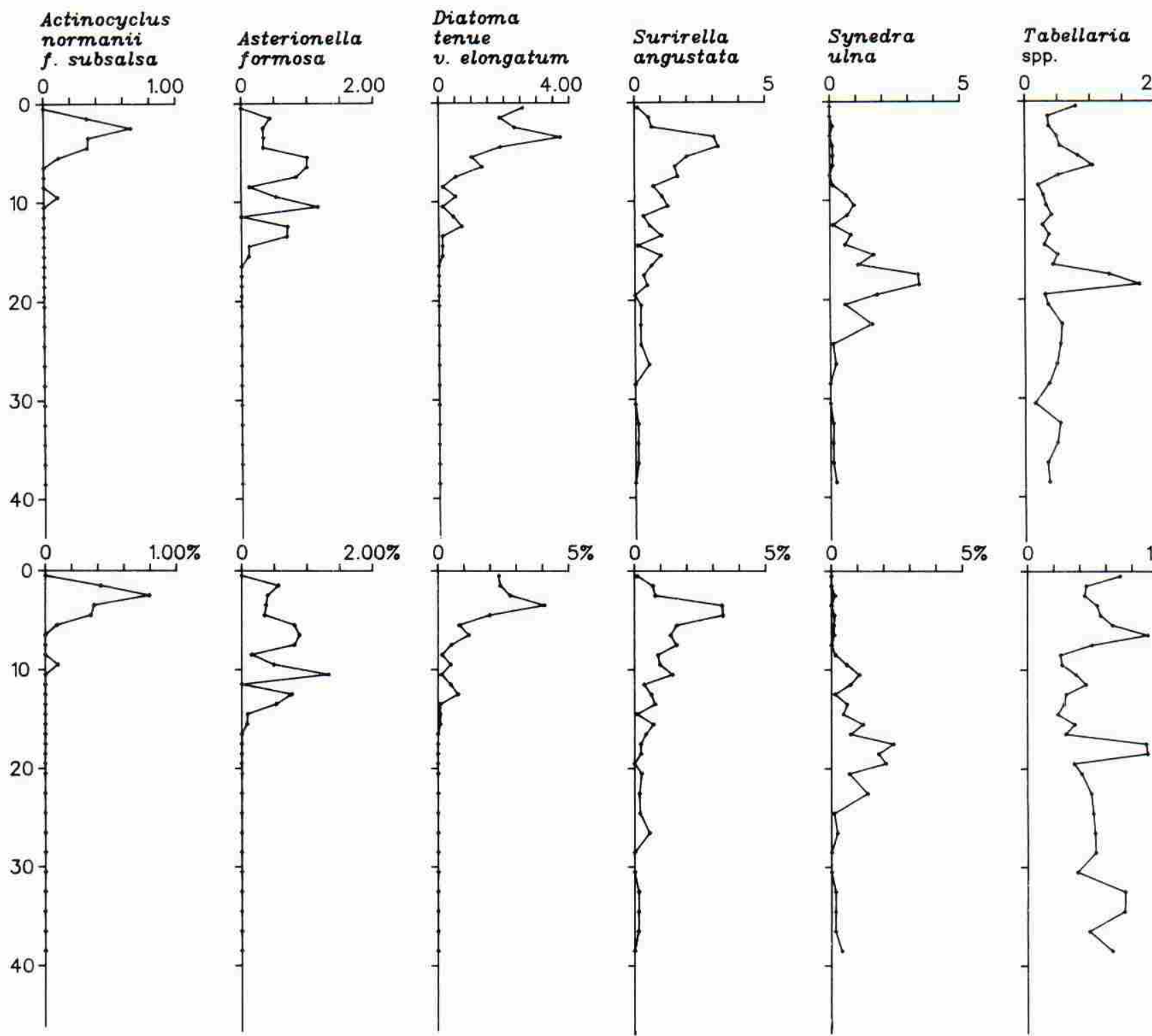

Fic. 8. Absolute (upper panel) and relative (lower panel) abundance of other diatom species abundant in core. Units are as in Figure 2.

It begins a pronounced rise in abundance at sample 8 (1945) which continues to the surface of the core. The form designated as chrysophycean cyst \#21 is abundant in the lower section of the core. It rises in abundance at sample 26 (1769), and reaches maximum abundance in sample 23 (1815). It declines in abundance after this and was last noted in sample 12 (1917).

The form designated as chrysophycean cyst \#23 is rare in our samples but occurs in samples $29(1719)$, 25 and 24 (1785-1900), 19-15 (1867-1896), and last in samples 11 and 10 (1924-1932).

Dinobryon type cysts in our samples are mostly of a morphotype we have designated as Dinobryon cyst \#4. Except for sample 26 (1769), it is consistently present in sediments below $20 \mathrm{~cm}$ in the section. Maximum abundance was found in sample 27 (1752), and it becomes an insignificant part of the flora after sample 21 (1847), except for low level occurrences in samples 10 (1932) and 4 (1967).

Other Dinobryon cysts contribute mainly to abundance in the lowest two samples in the section (17041719 ) and in a few samples above $20 \mathrm{~cm}$. They also co-occur with \#4 in samples 4 and 10 .

Cluster analysis was used to summarize the trends in relative abundance shown by major populations in the core. Because many species occurred in very low abundance, only those which constituted $>0.5 \%$ of the total assemblage in several samples were included in the analysis. A list of populations included is given in Table 2 . Two cluster analyses were performed. The first includes all relatively abundant morphological entities, including the chrysophycean cyst morphotypes which cannot be adequately 

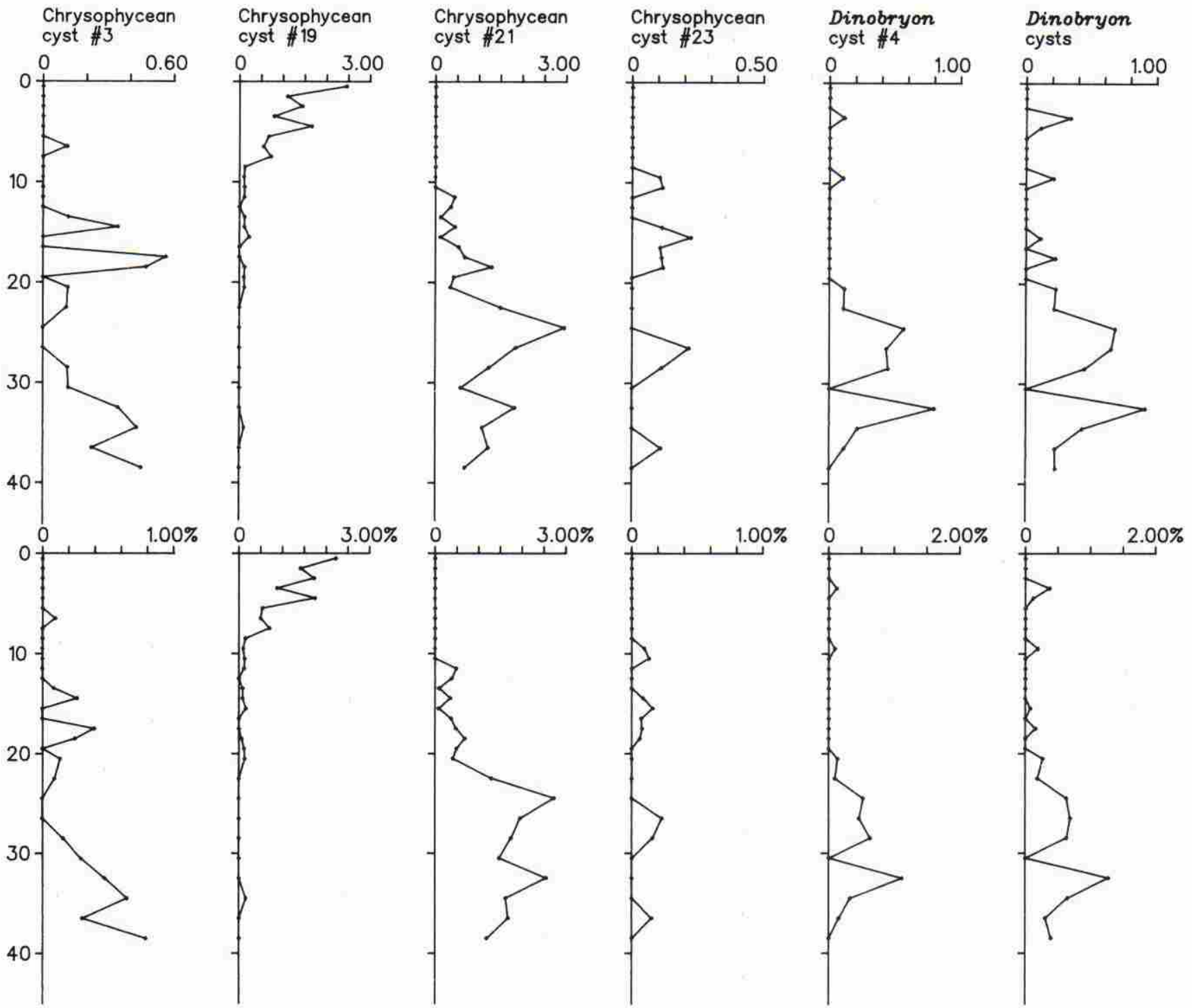

Fig. 9. Absolute (upper panel) and relative (lower panel) abundance of most abundant cyst morphotypes in core. Units are as in Figure 2.

identified. The second included only identified diatom populations.

Results of the first cluster analysis are shown in Figure 10. For convenience of discusssion, the samples are ordered chronologically, although samples 22 and 21 (1831-1847) form a high order outlier cluster (Zone B), as indicated by the dashed connection, and sample 26 (1769) is clustered with samples later in the section (i.e. with those in Zone C) as indicated by the bracket. It will be noted that the highest order of differentiation distinguishes samples deposited after ca. 1955 (samples 6 through 1) from all others. Within this cluster, we have distinguished three subzones: sample $6\left(\mathrm{E}_{1}\right)$, which is clearly distinguished from the rest of the samples, sample $1\left(\mathrm{E}_{3}\right)$, and the rest of the samples $\left(\mathrm{E}_{2}\right)$.

In the other large cluster (Fig. 10), samples 22 and 21 (1831-1847) are differentiated at a high level.
We have labeled them Zone B. The next dichotomy separates samples deposited prior to ca. 1900 from those deposited later. Within the latter group (Zone D), samples deposited prior to ca. $1935\left(\mathrm{D}_{1}\right)$ are distinguished from those deposited between ca. 1935 and $1955\left(\mathrm{D}_{2}\right)$. It should be noted that sample 9 (1938) is distinguished from other samples in the $D_{2}$ subzone at a quite high level.

The remaining samples are split into two large clusters. The first of these contains samples deposited between ca. 1853 and ca. 1900 (Zone C). The second contains samples deposited between ca. 1700 and ca. 1820 (Zone A), with the exception of sample 26 (1769) which clusters with samples in Zone C.

The cluster analysis using only diatom populations (Fig. 11) is essentially similar. Zones A, B, and C have the same time boundaries. We have subdivided Zone $\mathrm{C}$ to indicate the slight differences in samples 
deposited before $\left(C_{1}\right)$, and after $\left(C_{2}\right)$, ca. 1877. It should be noted that in this case, sample 26 (1769) clusters with the $\mathrm{C}_{2}$ group. The main difference is that the analysis based on only diatoms separates Zones D and E somewhat earlier, ca. 1950 rather than ca. 1955. It should be noted that sample 1 (1979) and sample 9 (1938) are still distinguished at a quite high level.

\section{DISCUSSION}

Our results clearly show a major change in composition of the Lake Ontario algal flora during the time period sampled by our core. Many populations have suffered local extinction, or at least have been reduced in abundance to below the detection limit of our analyses. Conversely, several populations have been introduced into the flora and have become abundant in the more recent samples. It is also clear that the floristic modifications observed can be attributed to eutrophication. Without exception, the populations displaced are those abundant in lakes receiving low to moderate nutrient loadings. Also without exception, introduced populations are characteristic of lakes receiving high to very high nutrient loads. Given the known history of Lake Ontario, this is not a surprising result.

The more interesting questions revolve around the timing of these changes, the mechanisms involved, and the characteristics of the Lake Ontario system which may result in different responses to changes in nutrient loading than those observed in other systems.

The first point of note in this regard is the fact that the increase in production which would be inferred from qualitative changes in the flora is not reflected by a steadily rising quantitative trend in siliceous microfossil abundance, as might be expected. Rather, the highest absolute numbers of siliceous microfossils are found in sample 19 (1859), and there is a general trend of decline in abundance both below and above this. A possible explanation for this apparent inconsistency might be that the pre-ca. 1860 trend is a true reflection of increased production and a continuing trend of increase after ca. 1860 is masked by increasing allochthonous sedimentation. Similar situations have been found associated with post-intensive agricultural sequences in other lakes (e.g. Battarbee $1978 \mathrm{a}, \mathrm{b}$ ). The ${ }^{210} \mathrm{~Pb}$ dates on our samples, however, do not support this theory. They indicate a uniform sedimentation rate during the period sampled by the core. This conclusion should be viewed with some caution. The lack of correspondence between diatom abundance and chemical measurement of biogenic silica in samples 26 and 21-22 might be interpreted as indication of increased allochthonous sedimentation in these samples.

Another interesting point is an apparent shift in seasonality of the diatom flora. Species which reach their maximum abundance at very low $\left(<4^{\circ} \mathrm{C}\right)$ tem-
TABLE. 2. Diatom taxa and cyst morphotypes induced in cluster analyses. Both the diatom taxa listed and the cyst morphotypes were included in the analysis shown in Figure 10. Only the diatom taxa were included in the analysis shown in Figure 11.

\begin{tabular}{|c|c|}
\hline $\begin{array}{l}\text { Achnanthes clevei Grun. } \\
\text { Actinocyclus normanii fo. subsal- } \\
\text { sa (Juhl.-Dannf.) Hust. } \\
\text { Asterionella formosa Hass. } \\
\text { Cyclotella comensis Grun. } \\
\text { C. comta (Ehrenb.) Kütz. } \\
\text {. comta var. radiosa Grun. } \\
\text { michiganiana Skv. } \\
\text { E. ocellata } \text { Pant. } \\
\text { C. stelligera (Cl. \& Grun.) V. H. } \\
\text { Diatoma tenue var. elongatum } \\
\text { Lyngb. } \\
\text { Fragilaria capucina Desm. } \\
\text { F. construens var. minuta } \\
\text { Temp. \& Per. } \\
\text { F. crotonensis Kitton } \\
\text { A. Cl. } \\
\text { F. pinnata Ehrenb. } \\
\text { Melosira distans (Ehrenb.) Kütz. } \\
\text { M. granulata (Ehrenb.) Ralfs } \\
\text { M. islandica O. Müll. } \\
\text { M. italica subsp. subarctica O. } \\
\text { Müll. }\end{array}$ & $\begin{array}{l}\text { Nitzschia acuta Hantz. } \\
\text { N. bacata Hust. } \\
\text { N. confinis Hust. } \\
\text { N. dissipata (Kütz.) Grun. } \\
\text { N. gracilis Hantz. } \\
\text { Nitzschia sp. \#1 } \\
\text { Nitzschia sp. \#2 } \\
\text { Stephanodiscus alpinus Hust. } \\
\text { S. binderanus (Kütz.) Krieg. } \\
\text { S. minutus Grun. } \\
\text { S. niagarae Ehrenb. } \\
\text { S. parous Stoer. \& Håkans. } \\
\text { S. transilvanicus Pant. } \\
\text { Stephanodiscus sp. \#10 } \\
\text { Stephanodiscus sp. \#19 } \\
\text { Stephanodiscus sp. \#20 } \\
\text { Surirella angusta Kütz. } \\
\text { Synedra ulna (Nitz.) Ehrenb. } \\
\text { et var. } \\
\text { Tabellaria fenestrata (Lyngb.) } \\
\text { Kütz. } \\
\text { T. flocculosa (Roth) Kütz. } \\
\text { Dinobyron cyst \#4 } \\
\text { chrysophycean cyst \#3 } \\
\text { chrysophycean cyst \#19 } \\
\text { chrysophycean cyst \#21 } \\
\text { chrysophycean cyst \#23 }\end{array}$ \\
\hline
\end{tabular}

peratures are present throughout the core. They tend to be present in low and stable relative abundance in Zone $\mathrm{A}$, increase through Zone $\mathrm{C}$, and reach a maximum in Zone $\mathrm{D}$ or early in Zone $\mathrm{E}$. An example of this type of response is Stephanodiscus alpinus (Fig. 7), a dominant population which occurs in maximum abundance at very low temperatures in Lake Ontario (Stoermer and Ladewski 1978) and in Lake Michigan (Stoermer and Ladewski 1976). The more abundant members of the genus Stephanodiscus in Lake Ontario have similar apparent temperature optima, hence the abundance trends for the genus (Fig. 7) reflect this type of behavior. Conversely, all populations which have relatively high apparent temperature optima that occur in Zone A reach maximum abundance in the mid-portion of the core, then decline to local extinction near the Zone D to Zone E boundary. Because all of these populations are now absent from the Lake Ontario flora, temperature information is inferred from Lake Michigan data (Stoermer and Ladewski 1976). This might be questioned, but their seasonal occurrence in Lake Michigan is consistent with other reports in the literature (e.g. Huber-Pestalozzi 1942), and the apparent temperature preferences of other populations which occur in both lakes are very similar (Stoermer and Ladewski 1976, 1978). Populations with intermediate $\left(4\right.$ to $\left.12^{\circ} \mathrm{C}\right)$ apparent temperature maxima may either survive (e.g. Melosira islandica) or decline and disappear from the flora (e.g. $M$. 


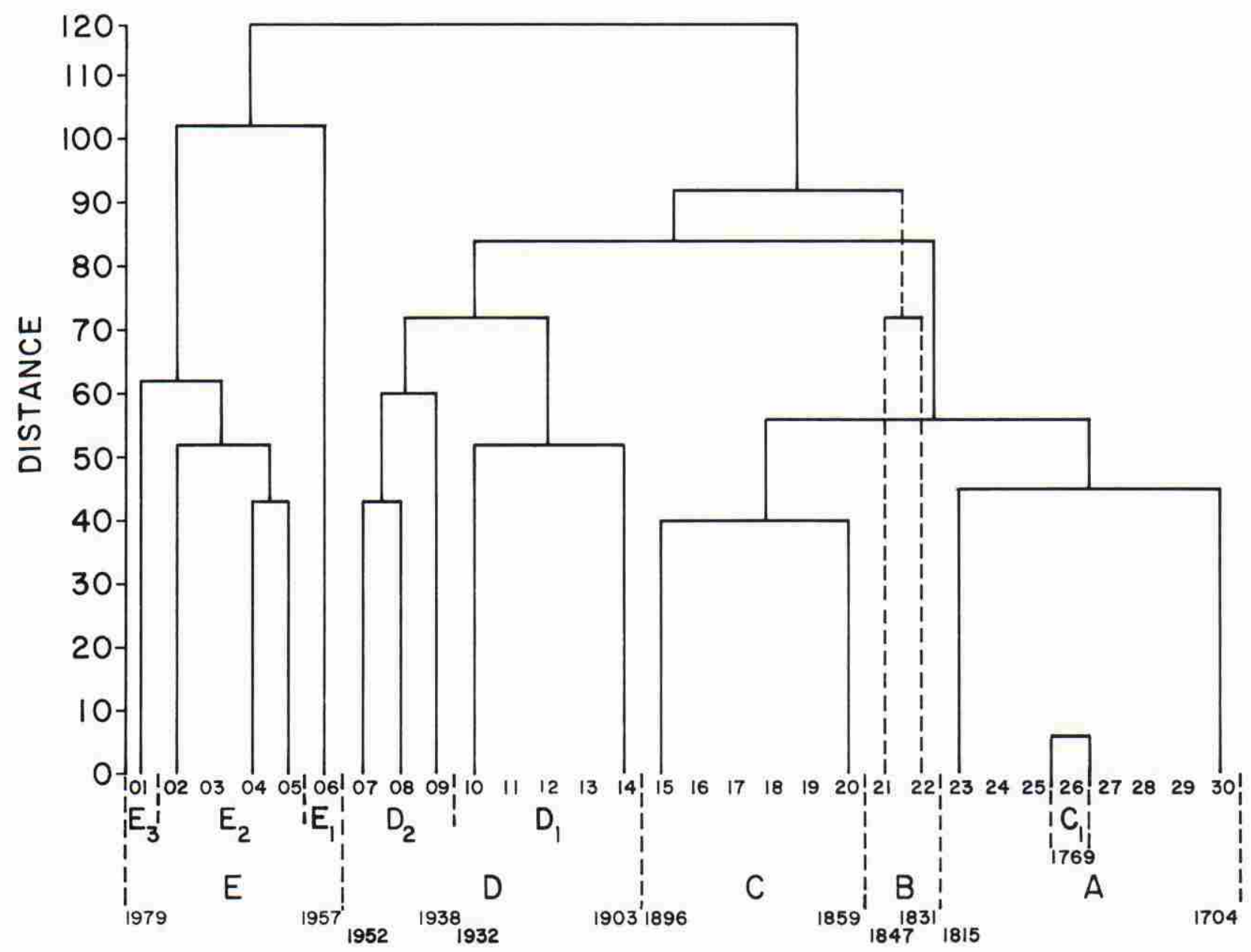

FIG. 10. Cluster analysis based on most abundant diatom and chrysophycean cyst morphotypes (see Table 2) in core. Vertical scale is in relative distance units. Horizontal scales are (from top to bottom) sample numbers, Zones and Sub-Zones of similarity inferred from the analysis, and dates associated with the Zone boundaries.

italica subsp. subarctica). Populations which replace the thermophilic species and become more important in Zone D and especially in Zone E are: (1) eurytopic and apparently opportunistic species which have no clear temperature preferences, such as Asterionella formosa and Diatoma tenue var. elongatum (Stoermer and Ladewski 1976, 1978); (2) species which are particularly associated with spring and fall blooms in nearshore regions such as Fragilaria capucina (Stoermer et al. 1974) and Stephanodiscus binderanus (Lorifice and Munawar 1974); (3) populations associated with extremely eutrophied regions such as Actinocyclus normanii fo. subsalsa (Stoermer 1978); or (4) benthic populations.

Another obvious point is the fact that many populations which are present throughout the core undergo changes in morphology, to varying degrees, over time. We have not yet made a detailed morphometric analysis of these changes, but they are in some cases so obvious that they bear comment. The clearest case is Melosira granulata which switch- es entirely from the gamma status growth form to the alpha status growth form (Fig. 5). Among the more abundant species, $M$. islandica changes from dominance of the most coarsely structured morph in Zone A to dominance of the mostly finely structured form in Zone E. Populations of Stephanodiscus niagarae in samples from this core appear to undergo the same transition in morphology described by Theriot and Stoermer (1984) for similar populations in Lake Erie. A similar change from coarsely structured morphotypes over time was also noted in $S$. alpinus. Although further research will be necessary to quantify these trends, on the basis of Theriot and Stoermer's (1984) results, they appear to indicate a decrease in the available $\mathrm{Si}: \mathrm{P}$ ratios in Lake Ontario over time.

We feel that the trends in absolute and relative abundance of siliceous microfossils in Lake Ontario sediments furnish some insight into the progression of ecological change in the lake and are suggestive of certain dominant mechanisms. The nature of some 


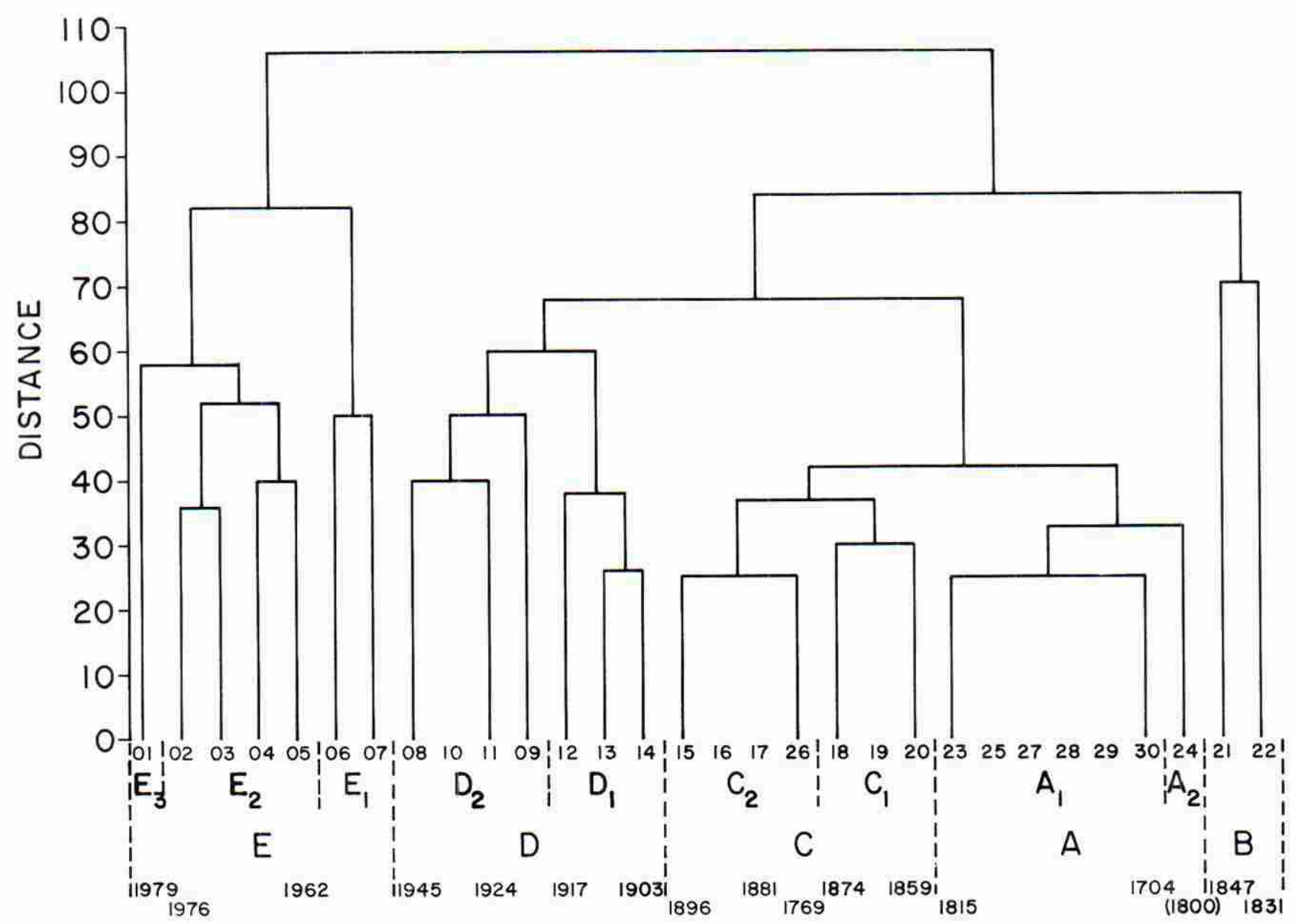

Fig. 11. Cluster analysis based on most abundant diatom taxa only (see Table 2) in core. Scales and units are as in Figure 10.

events in the record is not entirely clear and the operational details of some mechanisms are not fully understood but the basic outline is reasonably clear.

It is our conclusion that the lower half of Zone A, representative of the time period between ca. 1700 and ca. 1770 , is representative of Lake Ontario in quasi-equilibrium with its natural environment, prior to large-scale human intervention. The algal species present are tolerant of low to moderate nutrient availability. It is noteworthy that, even at this time, there appeared to be a distinction between species which occur during the cold periods of the year and those which occur primarily during the summer stratified period. Many of the species which reach their maximum abundance during the colder months of the year have a long range of temporal occurrence in Lake Ontario and a wide range of geographic occurrence in lakes of differing trophic status. This implies that these species' primary adaptation to conditions in Lake Ontario is the ability to survive low temperatures and prolonged periods of light limitation, either during winter circulation or below the summer thermocline. Summer forms, on the other hand, appear to be species which tol- erate stringent nutrient, particularly phosphorus, limitation. We assume that other nutrients were not limiting. The excellent preservation of even very small diatom fragments (Fig. 2) and the fact that diatom morphotypes present are those characteristic of growth under silica-sufficient conditions argue that silica was present in excess of nutritional needs. Because of the drainage characteristics of the Great Lakes, it is highly probable that nitrogen was present in excess. The sedimentary assemblages produced by growth under these conditions contain a good representation of both "oligotrophic" summer and winter forms and representatives of winter species which thrive with moderate phosphorus enrichment.

It is clear that some major event occurred in the interval represented by sample 26 (ca. 1769). Although we cannot point to a specific historical event, or series of events, at this time, it is reasonably clear that the effect was mild eutrophication of the Lake Ontario system. According to the cluster analysis results (Figs. 10,11), remains of the flora deposited at this time are more similar to those produced in Zone $\mathrm{C}$ than to associations found in other samples 
in Zone A. It will be noted that the primary negative effects are on chrysophyte species (Figs. 2 and 9), and on the most sensitive diatom species (e.g. Cyclotella ocellata, Fig. 3). Conversely, the main positive effects are on the more nutrient-tolerant summer (e.g. Clyclotella comta, Fig. 3) and winter (Stephanodiscus niagarae, Fig. 7) species. Since total production is apparently reduced, it might be argued that sample 26 records the effects of some toxic insult to the system or a fairly major climatic perturbation. Neither of these hypotheses can be discarded, but the former would seem rather unlikely. As we will discuss below, the most likely hypothesis appears to be that this episode marked the beginning of anthropogenic nutrient effects on the Lake Ontario system.

The portion of Zone A above sample 26 is characterized by incresing production and the introduction of some species which show rapid increase in response to phosphorus loading in the upper Great Lakes (e.g. Cylotella stelligera, Fig. 3), and some more eurytopic species (e.g. Fragilaria crotonensis, Fig. 4). It is our conclusion that this period represents the response of a well integrated primary producer community to slightly increased nutrient loading. Production is increased with minimal change in the qualitative aspect of the flora. The situation would be similar to that discussed by Parsons et al. (1972), where initial fertilization of an oligotrophic lake increases the quantity of primary production but has little effect on the quality of production, since species composition of the flora is not greatly altered.

The next event horizon in the core, Zone B, is much more significant in terms of subsequent effects on the Lake Ontario system. It is clear that Zone B is the analogue of "settlement horizon" usually determined by a sharp increase in Ambrosia pollen. It marks the effects of major deforestation and introduction of large-scale agriculture to the region. This zone is characterized by a marked decline in most chrysophyte populations and a rather subtle increase in the abundance of diatom populations favored by more eutrophic conditions although there is an apparent decrease in total production. It is also marked by the first major increase in summer blooming diatom species such as Cyclotella comensis and $C$. stelligera (Fig. 3). The major effect on the system appears to have been stimulation of summer production as well as possible introduction of secondary nutrient, in this case silica, limitation.

Zone C, covering the period from ca. 1860 to ca. 1900 , is representative of conditions similar to those found in the more oligotrophic regions of the modern Great Lakes. Most important elements of the indigenous flora are still present, although a few species particularly associated with Zone B or the later part of Zone A, such as Fragilaria construens var. minuta (Fig. 4) and Melosira distans (Fig. 5), drop below detectable levels. The production and preservation of siliceous microfossils is higher in Zone $\mathrm{C}$ than in any other zone, but there is a declining trend in absolute siliceous microfossil accumulation (Fig. 1) during the period. The qualitative evidence, however, suggests that there was a slight relaxation of nutrient loading in Zone $\mathrm{C}_{1}$ compared to Zone $\mathrm{B}$, and that this was followed by further increases in Zone $\mathrm{C}_{2}$. This does not appear unreasonable, since revegetation and stabilization of the landscape following the effects of early intensive settlement could have reduced nutrient loads. The important point is that some factor clearly began to limit the production and/or preservation of siliceous microfossils in Lake Ontario during this period. The most likely cause appears to be secondary silica limitation (Schelske and Stoermer 1971, 1972). We would also speculate that Zone $\mathrm{C}$ may have been the most effectively productive period in the recent history of Lake Ontario. Primary production had clearly been increased, but not to the point where secondary effects became disruptive of ecosystem structure and function.

Zone D apparently marks the beginning of such effects. The Zone C to Zone D boundary, ca. 1900, marks the first local extinction of major populations (e.g. Fragilaria intermedia var. fallax, Fig. 4), and the beginning of terminal decline for others (e.g. Melosira italica, Fig. 5). All species of the oligotrophic Cyclotella association (Hutchinson 1967) present in Lake Ontario became locally extinct during this period, along with other populations characteristic of least disturbed regions in the upper Great Lakes (e.g. Stephanodiscus transilvanicus, Fig. 7). The important taxa replacing them were species characteristic of very eutrophic lakes (e.g. Stephanodiscus parous, Fig. 7), and a number of eurytopic species such as Asterionella formosa (Fig. 8) and Diatoma tenue var. elongatum (Fig. 8). It apparently was during this period that increased phosphorus loadings resulted in sufficient increase in epilimnetic production by non-siliceous phytoplankton species to "shade out" the deep plankton refugium (Moll and Stoermer 1982), and thus eliminate major parts of the indigenous flora. Our results thus indicate that major modifications of the production base in Lake Ontario began as early as 1900 and the composition and seasonality of primary production had been severely modified by the end of Zone $\mathrm{D}_{1}$ (Fig. 11), ca. 1920 . By the end of Zone $\mathrm{D}_{2}$, ca. 1945, Lake Ontario had arrived at a condition that might be termed eutrophic but is probably better designated as severely anthropogenically modified.

The final sequence in the core, Zone E, evidently records the effects of human population growth, increased sewering, and the introduction of phosphate-based detergents which resulted in extreme phosphorus loadings to Lake Ontario. The floristic effects of this high phosphorus loading have few direct analogues in other lakes, apparently because of the unique characteristics of the Great Lakes system. Production and/or preservation of siliceous microfossils decreased even further apparently be- 
cause of year-round silica limitation which limits growth of even the most stenothermal species (e.g. Stephanodiscus alpinus, Fig. 7). The assemblages which are preserved contain a high proportion of strictly benthic diatoms (Fig. 2), meroplanktonic species (e.g. Surirella angustata, Fig. 8), and particularly species which are most abundant in the nearshore zone of the lake proximal to sources of silica supply (e.g. Stephanodiscus binderanus, Fig. 7). One of the most interesting characteristics of Zone $\mathrm{E}$ is the unusual abundance of Nitzschia spp. (Fig. 6). Because these taxa are rarely abundant in the plankton of large lakes, little is known about their ecology or nutrient requirements. Cholnoky (1968) suggested that many species of Nitzschia require organic nitrogen substrates for maximal growth, on the basis of observational evidence. It may be that the high levels of organic production and water column decomposition furnished optimal growth conditions for these species during this particular period. Floristic modifications in the surficial sediments (Zone $E_{3}$ ) suggest some recent relaxation of phosphorus loadings, which is in agreement with water chemistry records accumulated from the early 1970 s to the present (Dobson 1981).

In summary, this study indicates that the sediments of Lake Ontario record a long history of modification of the phytoplankton flora, dating virtually to earliest European settlement. Our results emphasize the importance of phosphorus as a controlling factor and the importance of secondary nutrient limitation. It also emphasizes the importance of any particular species' physical niche in determining its response to modified nutrient supply (Stoermer 1984b). Finally, our results support the conclusion that excessive phosphorus loading was a major factor in modifying the entire Lake Ontario ecosystem. Substantial changes in the primary production base occurred well in advance of similar changes at higher trophic levels (Beeton 1969) and no other mechanisms need be invoked to explain them. Biotic control from higher trophic levels to lower doubtless has some influence, but our results indicate that basic resources play the most important role in Lake Ontario as they appear to in smaller lakes (Carney 1982).

We wish to thank Dr. R. A. Bourbonniere for providing material used in the study and Dr. J. A. Robbins for providing ${ }^{210} \mathrm{~Pb}$ dates. The investigation was supported by Grant No. R810396 from the U.S. Environmental Protection Agency and Grant No. OCE8216588 from the National Science Foundation.

Andresen, N. A. 1976. Recent diatoms from Douglas Lake, Cheboygan County, Michigan. Ph.D. thesis, Univ. Michigan, Ann Arbor, 419 pp.

Battarbee, R. W. 1978a. Relative composition, concentration and calculated influx of diatoms from a sediment core from Lough Neagh, Northern Ireland. Pol. Arch. Hydrobiol. 25:916.

$1978 \mathrm{~b}$. Biostratigraphical evidence for variations in the recent pattern of sediment accumulation in Lough Neagh. Verh. Internat. Verein. Limnol. 20:624-9.

1979. Diatoms in lake sediments. In Berglund, B. E. [Ed.] International Geological Correlation Programme Project 158, Paleohydrological Changes in the Temperate Zone in the Last 15,000 Years. Subproject B, Lake and Mire Environments. Vol. II. Specific Methods. Dept. Quaternary Geology, Lund, 340 pp.

Beeton, A. M. 1965. Eutrophication of the St. Lawrence Great Lakes. Limnol. Oceanogr. 10:240-54.

1969. Changes in the environment and biota of the Great Lakes. In Eutrophication: causes, consequences, correctives. Proc. Nat. Acad. Sci., U.S.A., pp. 150-87.

Brunel, J. 1956. Addition du Stephanodiscus binderanus á la flore diatomique de l'Amérique du Nord. Nat. Can. 83:89-95.

Carney, H. J. 1982. Algal dynamics and trophic interactions in the recent history of Frains Lake, Michigan. Ecology 63:181426.

Cholnoky, B. J. 1968. Die Ökologie der Diatomeen in Binnengewässern. J. Cramer, Lehre, 699 pp.

Davis, C. O. \& Simmons, M. S. 1979. Water chemistry and phytoplankton field and laboratory procedures. Univ. Michigan, Great Lakes Res. Div. Spec. Rep. No. 70.73 pp.

DeMaster, D. J. 1979. The marine budgets of silica and ${ }^{32} \mathrm{Si}$. Ph.D. thesis, Yale University, New Haven, Conn, 308 pp.

1981. The supply and accumulation of silica in the marine environment. Geochim. Cosmochim. Acta 45:1715-32.

Dobson, H. H. 1981. Trophic conditions and trends in the Laurentian Great Lakes. W. H. O. Water Qual. Bull. 6:146-51, 158-60.

Dobson, H. H., Gilbertson, M. \& Sly, P. G. 1974. A summary and comparison of nutrients and related water quality in Lakes Erie, Huron and Superior. J. Fish. Res. Board Can. 31: 731-8.

Duthie, H. C. \& Sreenivasa, M. R. 1971. Evidence for the eutrophication of Lake Ontario from the sedimentary diatom succession. In Proc. 14th Conf. Great Lakes Res., Internat. Assoc. Great Lakes Research. pp. 1-13.

Ehrenberg, C. G. 1846. Neue Untersuchungen über das kleinste Leben als geologisches Moment. Ber. Akad. Wiss. Berlin. 1845: 53-88.

Frederick, V. R. 1981. Preliminary investigation of the algal flora in the sediments of Lake Erie. J. Great Lakes Res. 7: 404-8.

Gasse, F. 1980. Les diatomées lacustres plio-pleistocenes du Gadeb. Rev. algal., mem. hors-ser. 3:1-249.

Glover, R. M. 1982. Diatom fragmentation in Grand Traverse Bay, Lake Michigan and its implications for silica cycling. Ph.D. thesis, Univ. Michigan, Ann Arbor, 204 pp.

Håkansson, H. \& Locker, S. 1981. Stephanodiscus Ehrenberg 1846, a revision of the species described by Ehrenbert. Nova Hedw., Beih. 35:117-50.

Håkansson, H. \& Stoermer, E. F. 1984. Observations on the Type material of Stephanodiscus hantzschii Grunow in Cleve and Grunow. Nova Hedw. 39:477-95.

Hohn, M. H. 1969. Qualitative and quantitative analysis of plankton diatoms, Bass Island area, Lake Erie. Bull. Ohio Biol. Surv., n.s. 3:1-211.

Huber-Pestalozzi, G. 1942. Das Phytoplankton des Süsswassers, Teil 2, 2 Halfte. Diatomeen. In Thienemann, A. [Ed.] Die Binnengewässer, 16:366-549.

Hustedt, F. 1930. Die Kieselalgen Deutschlands, Österreichs und der Schweiz. In Dr. L. Rabenhorst's Kryptogamen-Flora von Deutschland, Österreich und der Schweiz. Bd. VII, Teil 1, 920 pp.

1949. Süsswasser-Diatomeen. Institut des Parcs Nationaux du Congo Belge. Exploration du Parc National Albert, Mission H. Damas (1935-1936). Imprimerie M. Hayex, Bruxelles, $199 \mathrm{pp}$.

Hutchinson, G. E. 1967. A Treatise on Limnology. Introduction to Lake Biology and the Limnoplankton. Vol. 2. John Wiley \& Sons, New York, $1115 \mathrm{pp}$.

Knudson, B. M. 1953. The diatom genus Tabellaria. II. The 
taxonomy and morphology of the plankton varieties. Ann. Bot., n.s. 17:132-55.

Lin, C. K. \& Blum, J. L. 1977. Recent invasion of a red alga (Bangia atropurpurea) in Lake Michigan. J. Fish. Res. Board Can. 34:2413-6.

Lorifice, G. J. \& Munawar, M. 1974. The abundance of diatoms in the southwestern nearshore region of Lake Ontario during the spring thermal bar period. In Proc. 17th Conf. Great Lakes Res., Internat. Assoc. Great Lakes Res., pp. 619-28.

Moll, R. A. \& Stoermer, E. F. 1982. A hypothesis relating trophic status and subsurface chlorophyll maxima of lakes. Archiv. Hydrobiol. 94:425-40.

Munawar, M. \& Nauwerck, A. 1971. The composition and horizontal distribution of phytoplankton in Lake Ontario during the year 1970. In Proc. 14th Conf. Great Lakes Res., Internat. Assoc. Great Lakes Res., pp. 69-78.

Nalewajko, C. 1967. Phytoplankton distribution in Lake Ontario. In Proc. 10th Conf. Great Lakes Res., Internat. Assoc. Great Lakes Res., pp. 63-9.

Ogawa, R. E. 1969. Lake Ontario phytoplankton, September, 1964. In Limnological Survey of Lake Ontario, 1964. Great Lakes Fish Comm. Tech. Rep. No. 14, pp. 27-38.

Parker, J. I. \& Edgington, D. N. 1976. Concentration of diatom frustules in Lake Michigan sediment cores. Limnol. Oceanogr. 21:887-93.

Parsons, R. T., Stephens, K. \& Takahashi, M. 1972. The fertilization of Great Central Lake. I. Effect on primary production. Fish. Bull. 70:13-23.

Patrick, R. \& Reimer, C. W. 1966. The Diatoms of the United States. Volume 1. Acad. Nat. Sci. of Philadelphia. Monograph No. 13,688 pp.

Robbins, J. A. 1978. Geochemical and geophysical application of radioactive lead. In Nriagu, J. O. [Ed.] The Biochemistry of Lead in the Environment, Elsevier North-Holland Biomedical Press, New York, pp. 285-393.

Robbins, J. A. \& Edgington, D. N. 1975. Determination of recent sedimentation rates in Lake Michigan using ${ }^{210} \mathrm{~Pb}$ and ${ }^{137} \mathrm{Cs}$. Geochim. Cosmochim. Acta 39:285-304.

Robbins, J. A., Edgington, D. N. \& Kemp, A. L. W. 1978. Comparative ${ }^{210} \mathrm{~Pb},{ }^{137} \mathrm{Cs}$, and pollen geochronologies of sediments from Lakes Ontario and Erie. Quat. Res. 10:256-78.

Schelske, C. L. \& Stoermer, E. F. 1971. Eutrophication, silica, and predicted changes in algal quality in Lake Michigan. Science (Washington, D.C.) 173:423-4.

1972. Phosphorus, silica, and eutrophication of Lake Michigan. In Likens, G. E. [Ed.] Nutrients and Eutrophication. Special Symposia Vol. 1, Amer. Soc. Limnol. Oceanogr., Allen Press, Lawrence, pp. 157-71.

Schelske, C. L., Feldt, L. E., Santiago, M. A. \& Stoermer, E. F. 1972. Nutrient enrichment and its effect on phytoplankton production and species composition in Lake Superior. In Proc, 15th Conf. Great Lakes Res., Internat. Assoc. Great Lakes Res., pp. 149-65.

Schelske, C. L., Stoermer, E. F., Conley, D. J., Robbins, J. A. \& Glover, R. M. 1983. Early eutrophication in the lower Great Lakes: new evidence from biogenic silica in sediments. Science (Washington, D.C.) 222:320-2.

Schenk, C. F. \& Thompson, R. E. 1965. Long-term changes in water chemistry and abundance of plankton at a single sampling location in Lake Ontario. Univ. Michigan, Great Lakes Res. Div. Pub. No. 13, pp. 197-208.

Sicko-Goad, L., Stoermer, E. F. \& Ladewski, B. G. 1977. A morphometric method for correcting phytoplankton cell volume estimates. Protoplasma 93:147-63.

Skvortzow, B. W. 1937. Diatoms from Lake Michigan. 1. Am. Mid. Nat. 7:652-8.

Smith, S. H. 1972. Destruction of the ecosystem in the Great Lakes and possibilities for its reconstruction. Univ. Wash. Pubs. in Fisheries, New Ser. 5:41-6.

Stoermer, E. F. 1968. Nearshore phytoplankton populations in the Grand Haven, Michigan, vicinity during thermal bar conditions. In Proc. 11th Conf. Great Lakes Res., Internat. Assoc. Great Lakes Res., pp. 137-50.
1978. Phytoplankton as indicators of water quality in the Laurentian Great Lakes. Trans. Am. Microsc. Soc. 99:2-16.

1984a. Limnological characteristics of northern Lake Michigan, 1976. Part 2. Phytoplankton population studies. Univ. Michigan, Great Lakes Res. Div. Spec. Rep. No. 95. pp. 127-245.

1984b. Research on Great Lakes algal communities: problems from the past, lessons for the future. J. Great Lakes Res. 10:143-55.

Stoermer, E. F. \& Håkansson, H. 1984. Stephanodiscus parvus: Validation of an enigmatic and widely misconstrued taxon. Nova Hedw. 39:497-511.

Stoermer, E. F. \& Kreis, R. G. 1980. Phytoplankton composition and abundance in southern Lake Huron. U.S. Environmental Protection Agency, Duluth, Minnesota. USEPA Rep. No. EPA600/3-80-061. 384 pp.

Stoermer, E. F. \& Ladewski, T. B. 1976. Apparent optimal temperatures for the occurrence of some common phytoplankton species in southern Lake Michigan. Univ. Michigan, Great Lakes Res. Div. Spec. Rep. No. 18.48 pp.

- 1978. Phytoplankton Associations in Lake Ontario during IFYGL. Univ. Michigan, Great Lakes Res. Div. Spec. Rep. No. 62, 106 pp.

Stoermer, E. F. \& Theriot, E. C. 1983. Phytoplankton composition and distribution in Saginaw Bay. Final Report to U.S. Environmental Protection Agency, Office of Research and Development, Duluth, $199 \mathrm{pp}$.

Stoermer, E. F. \& Yang, J. J. 1969. Plankton diatom assemblages in Lake Michigan. Univ. Michigan, Univ. Michigan, Great Lakes Res. Div. Spec. Rep. No. 47, 168 pp.

- 1970. Distribution and relative abundance of dominant plankton diatoms in Lake Michigan. Unit. Michigan, Great Lakes Res. Div. Publ. No. 16, 64 pp.

Stoermer, E. F., Bowman, M. M., Kingston, J. C. \& Schaedel, A. L. 1974. Phytoplankton composition and abundance in Lake Ontario during IFYGL. Univ. Michigan, Great Lakes Res, Div. Spec. Rep. No. 53, 373 pp.

Stoermer, E. F., Kingston, J. C. \& Sicko-Goad, L. 1979. The morphology and taxonomic relationships of Stephanodiscus binderanus var. oestrupi (A.C1.) A.C1. Nova Hedw, Beih. 64: 65-78.

Stoermer, E. F., Kreis, R. G., Jr. \& Sicko-Goad, L. 1981. A systematic, quantitative, and ecological comparison of $\mathrm{Me}$ losira islandica O. Müll. with $M$. granulata (Ehr.) Ralfs from the Laurentian Great Lakes. J. Great Lakes Res. 7:345-56.

Stoermer, E. F., Ladewski, B. G. \& Schelske, C. L. 1978. Population responses of Lake Michigan phytoplankton to nitrogen and phosphorus. Hydrobiologia 57:249-65.

Theriot, E. C. 1983. Morphological variation in Stephanodiscus niagarae (Bacillariophyceae). Ph.D. thesis, Univ. Michigan, Ann Arbor, Michigan, 145 pp.

Theriot, E. C. \& Stoermer, E. F. 1982. Observations on North American populations of Stephanodiscus (Bacillariophyceae) species attributed to Friedrich Hustedt. Trans. Am. Microsc. Soc. 101:368-74.

- 1984. Principal components analysis in character variation Stephanodiscus niagarae Ehrenb.: Morphological variation related to lake trophic status. Proc. VIIth Internat. Diatom Symp., Otto Koeltz, Koenigstein, pp. 97-111.

Vaughn, J. C. 1961. Coagulation difficulties of the south district filtration plant. Pure Water 13:45-9.

Vollenweider, R. A., Munawar, M. \& Stadelmann, P. 1974. A comparative review of phytoplankton and primary production in the Laurentian Great Lakes. J. Fish. Res. Board Can. 31:739-62.

Warwick, W. F. 1980. Paleolimnology of the Bay of Quinte, Lake Ontario: 2,800 years of cultural influence. Can. Bull. Fish. Aquat. Sci. 206:1-115.

Weiler, R. R. 1981. Chemistry of the North American Great Lakes. Verh. Internat. Verein. Limnol. 21:1681-94.

Wolfe, T. L. \& Sweeney, R. A. 1982. Laurentian Great Lakes Cladophora annotated bibliography. J. Great Lakes Res. 8:20137. 
This document is a scanned copy of a printed document. No warranty is given about the accuracy of the copy. Users should refer to the original published version of the material. 